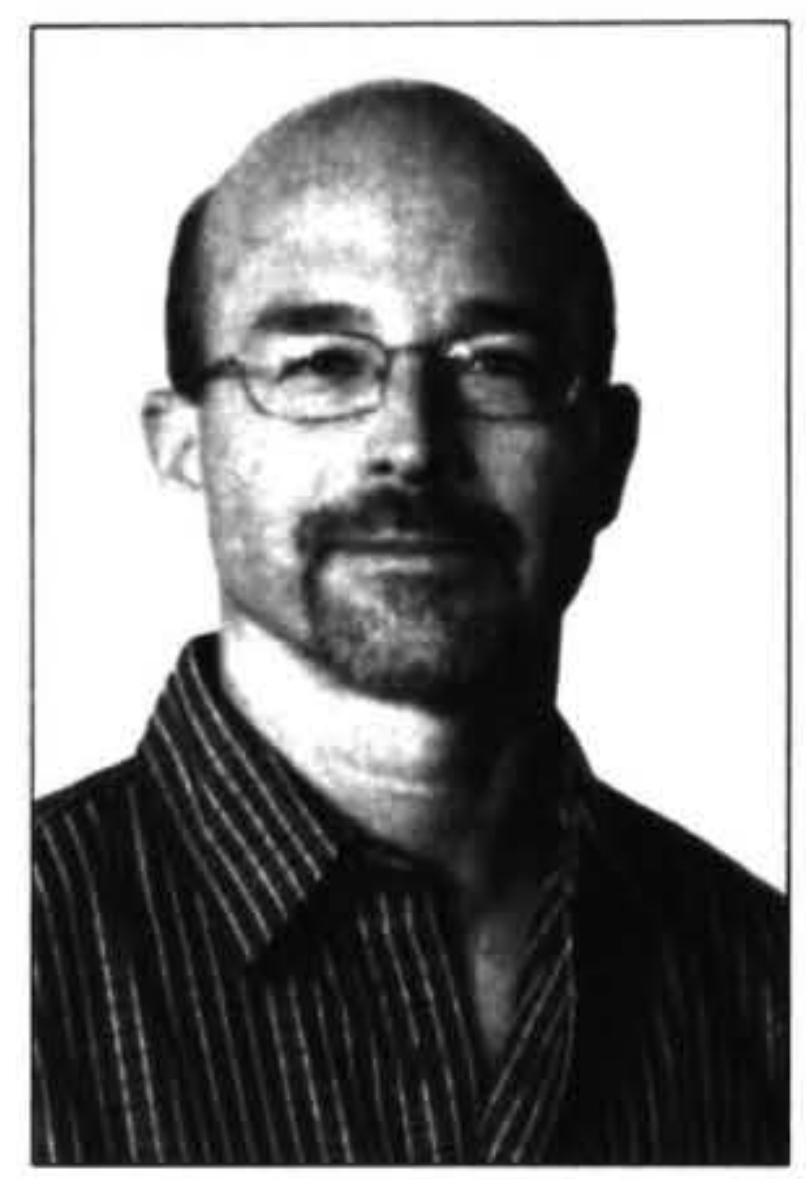

\title{
AN ANALYSIS OF JOB MOBILITY AND \\ EARNINGS IN NEW ZEALAND ${ }^{\prime}$
}

\author{
Tim Maloney
}

Economics Department,

The University of Auckland

\begin{abstract}
The movement of workers hetween jobs may play an important role in determining hoth the average level and overall dispersion in earnings in an econom: Yet, there has been almost no research to date on the extent and nature of job mobility and its possible consequences for individual earnings in New Zealand. This study provides some initial empirical results on this topic using administrative data provided by. Statistics New Zealand (Linked EmployeeEmployer Data). We find that job mohility is extensive. hut that high rates of joh separation during the first year or two in a joh eventually dissipate with tenure. Joh mohility is generally higher among teenagers and young adults, but differences by gender are minimal. In fact, overall joh mohility is generally higher for men than women. Individuals changing johs receive monthly earnings that are. on arerage, helow the earnings received by individuals who do not change jobs. We find that joh changes are associated with a narrowing in this earnings gap. Earnings growth is, on arerage. higher for those who change johs than for those who stay with the same emplover. However, this result disappears once we control for a wide variety of other determinants of earnings growth. Firm characteristics appear to pla! important roles in the relationship hetreen job mohility and eannings. A move to a larger firm (i.e one with more employees) and a firm that pays higher arerage earnings to all its employees can result in a substantial increase in individual earnings. Earnings growth is also found to be negatively related to the time interval between jobs, and the initial earnings of the individual. Once we hold these individual and firm characteristics constant, however. job changes hy themselies lead to a relative decline in earnings growth.
\end{abstract}

\section{Introduction}

We know little about the extent and nature of job mobility in New Zealand. Similarly, the link between job mobility and earnings has never been thoroughly investigated in this country. The purpose of this study is to provide some preliminary empirical findings on the movement of workers between jobs, and the consequences of this job mobility for the earnings received by these individuals. The underlying notion is that job mobility may play an integral role in the determination of the average level of earnings, as well as the dispersion of earnings, in the economy.

The primary reason for our lack of knowledge about job mobility and its consequences for earnings in New Zealand is the unavailability, until now, of a suitable longitudinal database for this type of research. Panel data, allowing us to follow the same individuals over time, are rare in New Zealand. The Dunedin Multidisciplinary Health and Development Study and the Christchurch Health and Development Study continue to follow two cohorts of children born in these respective metropolitan areas in the 1970's. However. these are relatively small samples that are largely restricted to specific geographic areas, and these databases are only infrequently updated. ${ }^{2}$ A panel could be constructed from a survey instrument like the Household Labour Foree
Survey that contains an eight-quarter rotation group framework. However, such a panel would be limited to a two-year period and earnings information would be restricted to a single quarter each year when earnings and income data are solicited.

At this point, administrative data provide the best option for empirically analysing job mobility in New Zealand. Administrative data have a particularly advantage for this project, because recent overseas studies using similar data have shown the importance of employer characteristics in the determination of both job mobility and earnings. Linked Employer-Employee Data (LEED) have been provided by Statistics New Zealand to carry out this analysis of job mobility and its consequences for earnings to New Zealand.

The structure of this remaining report is as follows. Section 2 provides a brief review of the relevant overseas literature in this area. Section 3 summarises the characteristics of the LEED database, discusses the advantages and disadvantages of these data for the specific research questions addressed in this project and presents some descriptive statistics on job mobility and earnings Section 4 presents the results from a regression analysis on the potentially complex links between job mobility and the earnings of individuals. 


\section{A Brief Literature Review}

Two basic facts appear to characterise job mobility in most countries. Most new jobs end early (i.e., frequent early job separations), and long-term employment relationships are common (i.e., lengthy job tenure). For example, nearly one-quarter of US workers in 1996 between the ages of 20 and 64 were in their current jobs for less than one year. Yet, more than one-quarter of US workers examined in the same year between the ages of 45 and 64 had held their jobs for at least 20 years (Farber 1999).

These facts are not contradictory. They simply suggest that there is a great deal of churning of workers in new jobs (especially early in the work life). Yet, employeeemployer matches that survive these first few years tend to be relatively long-lived. As a result, hazard rates (the probability of a job ending conditional on some elapsed time in the job) decline substantially with tenure.

There are competing hypotheses for the observed decline in hazard rates. They could be attributed to worker heterogeneity (mobility could be largely relegated to workers who are inherently predisposed to high levels of job turnover), or they could be attributed to state dependence (early mobility may itself directly lead to subsequent mobility). The literature suggests that both explanations have merit, but that unobserved heterogeneity alone can not entirely explain the mobility patterns that are found (e.g., see Farber 1999 and Munasinghe and Sigman 2003).

One issue that has received a great deal of attention in this literature is whether or not job mobility has increased or declined in magnitude over recent decades. The results are mixed for the US. Swinnerton and Wial (1995) find some evidence for a general increase in job mobility during the 1980 's, but subsequent work by Diebold et al. (1998) and Farber (1998) dispute this conclusion and find no obvious trend in overall job mobility.

The association between job mobility and earnings also has been examined over the years by both economists and other social scientists. Sociologists have noted that job mobility is generally negatively correlated with earnings. This is sometimes referred to as the "hobo syndrome" (e.g., see Munasinghe and Sigman 2003), and is often attributed to personal characteristics, like lack of commitment or motivation, that simultaneously result in weaker job attachment and lower wages (either through the expenditure of less effort on the job or reduced human capital investments).

Economists have suggested that the reason behind a job separation is often a key factor in determining whether the relationship between job mobility and earnings change is generally positive or negative (e.g., see Borjas 1981, Gottschalk and Maloney 1985). On average, quits (voluntary separations that are initiated by the worker) result in wage gains. On average, layoffs, redundancies or plant closures (involuntary separations that are initiated by the employer) result in wage losses. The latter tends to dominate empirically, partly because expectations of future job mobility (initiated by either party) tend to reduce the incentives for investments in employerspecific human capital. Lower rates of human capital accumulation reduce growth rates in both productivity and associated earnings.

Both the positive and negative aspects of job mobility need to be emphasised in this literature. On the positive side, job mobility may be part of the functioning of a healthy labour market. Emphasis here is often placed on the quality of employee-employer matches. The key is that the interactions of the unique characteristics of both parties result in a particular productivity level. Since the exact quality of the match is uncertain a priori, either party (or both parties) may have an incentive to dissolve the specific match in favour of alternative matches. This 'churning' in the early stages of the work life may be advantageous to individuals, employers and society. Burgess et al. (2000) show that job security provisions in OECD countries both reduce job mobility and inhibit necessary adjustments in the labour market to periodic shocks.

On the negative side, job mobility destroys the productivity gains associated with long tenure. Although not often emphasised in this literature, these negative consequences should be related to either market failures or separations that result from exogenous shocks affecting either workers or firms. In the former, the parties who initiate the separation may not bear all of the costs associated with mobility. In the latter, the separation is simply imposed on the two parties. Both result in suboptimal levels of worker mobility (i.e., too many job transitions).

This overseas literature suggests that the relationship between job mobility and earnings is complex. Although job mobility is common, especially among younger workers, long job tenure is also frequently observed. Job matches formed between workers and firms often end early in the relationship. However, matches that survive this initial period are likely to persist for many years. Hazard rates are initially high, but decline substantially with job tenure.

The impact of job mobility on earnings is theoretically ambiguous. Even in a simple model of the labour market, it would be impossible to predict how job changes would affect the earnings of an individual. This is at least partly attributable to the different reasons for a job separation. Individuals who voluntarily quit their jobs would be more likely to experience an increase in earnings compared to individuals who involuntarily separate from their jobs. Yet, if this job mobility involves a subsequent search process after a job quit, the earnings in the new job could be either above or below the earnings in the previous job due to the uncertain outcome of a job search process.

Ultimately, the impact of job mobility on earnings is an empirical question. We can expect that job changes will result in both positive and negative changes in earnings. The key is to estimate the average relationship between job mobility and earnings, and to isolate the factors that are related to both positive and negative associations 
between these phenomena. In other words, what factors make it more or less likely that a job change will result in an increase in earnings for an individual?

\section{Data and Descriptive Statistics on Job Mobility and Earnings}

The LEED database provides an excellent platform for a research programme which examines the extent and nature of job mobility and its possible consequences for earnings of workers in New Zealand. This database merges monthly, individual PAYE data from the Inland Revenue Department (IRD) with the characteristics of their employers. This allows for the construction of complete monthly employment and earnings histories for nearly all employed individuals over the period beginning in April 1999.

Given recent studies that emphasise the importance of employer characteristics in the relationship between job mobility and earnings changes (e.g.. see Holzer et al. 2004), it is vitally important to have firm-level data for this project. With the time that has elapsed since the initiation of LEED, we now have a sufficiently long panel to begin to look at this overall research question.

There are several obvious deficiencies in the LEED data for this project:

- Lack of information on hours and weeks of work. Monthly PAYE earnings data are available for each individual, but there is no direct way of converting this into a measure of hourly earnings. This means, for example. that an increase in earnings between two jobs could be the result of an increase in the wage rate. hours of work or some combination of the two.

- Lack of tenure or employment history data prior to April 1999. This makes it difficult to describe accurately long-term employment relationships. For example, someone as of April 2005 would have their tenure censored at six years. We are forced to use the job mobility data within the sample period to make inferences about long-term job tenure.

- Lack of any information on the reasons behind job separations. No information is available on the reason behind any job turnover. We do not know whether separations were initiated by workers (i.e. quits) or firms (i.c., layoffs or redundancies). Thus. one of the key elements in identifying the association between job mobility and earnings is unavailable in the LEED database.

Despite these drawbacks, the LEED data provide a number of advantages for the analysis of job mobility and its impact on carnings.

- Large sample size. The LEED data capture nearly the entire population of employment relationships at any point in time. ${ }^{4}$ As we will see shortly, this database provides information on over one million observations in any year. Large samples improve the efficiency of our estimates, and make it possible to explore particular aspects of this job-mobilityearnings relationship within narrow subpopulations.

- Monthly reports on employment and earnings histories. At best, most panel studies update their databases annually. This means that we often have missing or inaccurate data on job transitions and associated earnings. Individuals are often asked to recall when job changes occurred. These data are prone to recall or measurement error. At the same time, earnings data are often recorded only at the time of each survey or for the overall period since the previous survey. In either case, these data make it difficult to know how this job change was related to changes in individual earnings. The LEED database provides monthly earnings data taken directly from employer reports to the IRD. Thus, we can observe month-to-month changes in earnings without problems associated with individual recall.

- Employer and Industry Characteristics. Most panels that survey individuals provide little information on the characteristics of the firm. Yet, recent studies suggest that things like firm size and relative pay levels can be closely related to the individual earnings and the overall quality of the employee-employer match. The LEED database provides monthly information on average earnings across all workers at the firm, the number of employees and the industry in which the employer is located. Furthermore, by aggregating the employer data by industry, we can construct variables like the average monthly earnings in the industry. Of course, it is ultimately an empirical question of the extent to which these employer and industry characteristics matter in isolating the impact of job changes on individual earnings.

\section{Employment and Earnings Histories and Job Tenure}

Our initial sample for this study, constructed from the LEED database, includes all individuals who were between the ages of 16 and 64 over our sample period. Table 1, which along with other tables and figures in this report can be found at the end of this document, displays some simple descriptive statistics from these workers across five adjacent annual periods. Each period includes earnings and employment histories running from April in one year to March in the following year. The first period runs from April 1999 to March 2000, and the final period runs from April 2003 to March 2004. Overall, this was a period characterised by a buoyant and expanding economy. Average annual real GDP growth was nearly 4.1 pereent over this five-year period (March 1999 to March 2004). This was considerably above the long-term trend growth rate in real GDP of 2.6 percent per year recorded since June 1987. The official unemployment rate, according to the Household Labour Force Survey, declined steadily from 7.1 percent in March 1999 to 4.2 percent in March 2004, while the average annual growth 
rate in employment over this five-year period was 2.4 percent

The bottom row of Table 1 shows the number of individual observations in each 12-month period used to compute these mean statistics. There were over 1.15 million individuals working between April 1999 and March 2000. This figure grew to more than 1.37 million between April 2003 and March 2004. This represents an increase of nearly one-fifth in these observations of individual workers, or an average annual growth rate of nearly 3.6 percent over this period. This is consistent with an expanding economy and the consequent growth in aggregate employment.

We know from these administrative records when and how often individuals have changed their employment situations. The mean numbers of jobs held over each twelve-month period are listed in the first row of Table 1. On average, individuals held somewhere between 1.16 and 1.20 jobs in each twelve-month period. Yet, the vast majority of individuals (somewhere between 83.2 and 85.8 percent) worked for only a single employer in each twelve-month period. These results provide evidence of a substantial level of job stability among working-age individuals in New Zealand.

The remainder of Table 1 displays some information on average monthly earnings from the LEED database. Mean nominal earnings increased from \$2,929 in the year ending in March 2000 to $\$ 3,390$ in the year ending in March 2004. This represents a 15.7 percent increase in nominal earnings over this five-year period. Because of price inflation, however, this growth in monthly earnings was much smaller in real terms. All earnings figures were inflated to January 2005 dollars using the Consumer Price Index. The five-year growth in real monthly earnings was approximately 6.5 percent. In terms of average annual growth rates, nominal earnings grew at a rate of 3.7 percent, while real earnings grew at a rate of 1.6 percent over this sample period.

Table 2 shows one of the observations on the jobs held by workers that cannot be found in other survey data sources in New Zealand (e.g., the Population Census, Household Labour Force Survey and Quarterly Employment Survey). These datasets do not provide information on the tenure workers have realised with their employers at the time of the survey. As a result, we know very little from other data sources about the amount of churning or job-changing behaviour in this country.

We first restrict our sample to those individuals who were working as of March 2001. We then count back and compute the number months that each individual had held a particular job. ${ }^{5}$ The proportions of workers holding their primary job as of March 2001 for less than 3, 6, 12, 18 and 24 months are recorded in Table 2. The same procedure is then used for individuals employed as of March 2002, 2003 and 2004. ${ }^{6}$ According to the resulting statistics, there is a substantial amount of job churning in the New Zealand labour market. Between 7.8 and 9.0 percent of workers as of March in each year had held their jobs for less than three months. Just under a onethird of workers had been in their jobs for less than one year, and nearly one-half had been in their jobs for less than two years.

The descriptive statistics in Tables 1 and 2 show patterns that are largely consistent with observations from other countries. Although long-term employment relationships are common, there is also a great deal of job mobility in the New Zealand labour market.

Table 1: Descriptive statistics on employment and earnings histories.

\begin{tabular}{lccccc}
\hline & \multicolumn{4}{c}{ For Year Ending: } \\
\cline { 2 - 6 } & March & March & March & March & March \\
Variables: & 2000 & 2001 & 2002 & 2003 & 2004 \\
\hline Mean Number of Jobs Over Previous Year & 1.17 & 1.20 & 1.17 & 1.16 & 1.19 \\
\% with a Single Job & $85.21 \%$ & $83.22 \%$ & $85.11 \%$ & $85.81 \%$ & $83.65 \%$ \\
Mean Nominal Monthly Earnings & $\$ 2,929.36$ & $\$ 2,947.25$ & $\$ 3,164.58$ & $\$ 3,282.17$ & $\$ 3,390.16$ \\
$\% \Delta$ Nominal Earnings from Previous Year & -- & $0.61 \%$ & $7.37 \%$ & $3.72 \%$ & $3.29 \%$ \\
Mean Real Monthly Earnings & $\$ 3,269.17$ & $\$ 3,209.56$ & $\$ 3,370.28$ & $\$ 3,420.02$ & $\$ 3,481.69$ \\
$\% \Delta$ Real Earnings from Previous Year & --- & $-1.82 \%$ & $5.01 \%$ & $1.48 \%$ & $1.80 \%$ \\
\hline Number of Observations & $1,150,882$ & $1,227,113$ & $1,227,845$ & $1,250,531$ & $1,372,496$ \\
\hline
\end{tabular}

Notes: Data provided by Statistics New Zealand from the Linked Employer-Employee Data (LEED). The base period in computing real earnings using the Consumer Price Index (CPI) is January 2005. The four-year average annual growth rates in nominal and real monthly earnings implied by these series are 3.72 percent and 1.60 percent, respectively. 


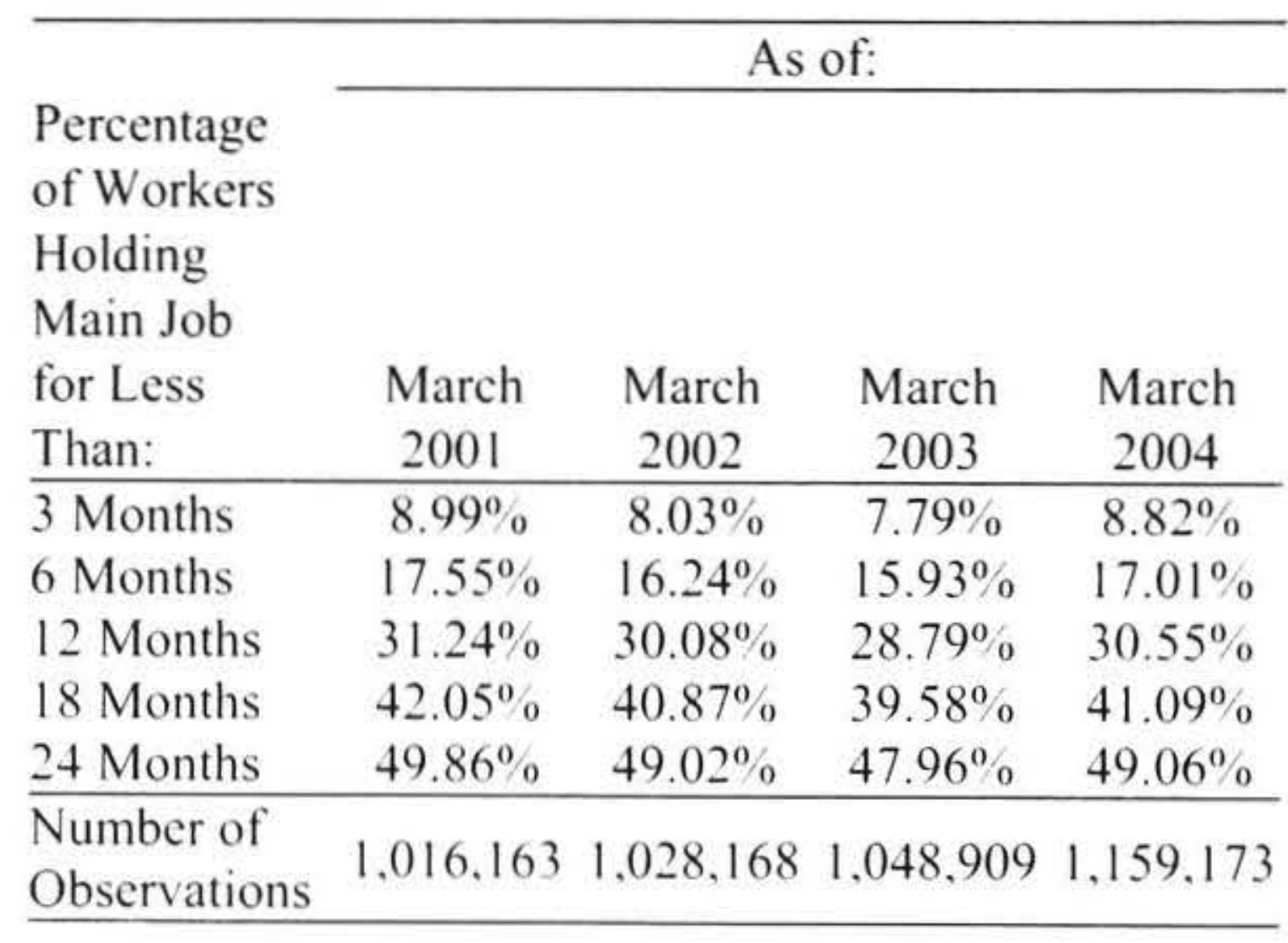

Notes: Data provided by Statistics New Zealand from the Linked Employer-Employee Data (LEED). The sample is restricted in March of each year to those who are employed. In cases of multiple jobs in that month. the one with the highest carnings is considered to be the primary job. A simple count of months in this primary job over the previous two years is used to establish job tenure. Given the restriction in the length of our sample period. the maximum tenure allowed is 24 months.

\section{Estimated Hazard and Survival Rates}

Another way of describing the nature of job mobility is to compute hazard rates using the LEED data. We do this by restricting the sample to individuals who had started a new employment spell between May 1999 and April 2000. These individuals are followed for a maximum of 52 months (four and one-third years). We then compute the proportion that continue in their jobs up to a given period, but terminate their spell in that month. This is an estimate of the probability of exiting employment in a given month conditional on surviving in that job until that point in time (i.e., a hazard rate). Another way of looking at the same behaviour is to compute the survival rates for these employment spells. This is the proportion of individuals who remain (or survive) in their jobs for a given number of months since the start of these employment spells. To see the importance of gender and age on these hazard and survival rates, the following figures display these results separately for males and females and for three different age groups ( 16 to 24, 25 to 45 , and 46 to 64 ).

Two fairly consistent results found overseas are that hazard rates increase initially over the first few months in the job, but then always fall precipitously after that period (e.g.. see Farber 1999). The former result is presumably because the quality of the job match isn't realised for several months. Once both workers and firms are able to assess the quality of the match, job separations become more likely. The second result is most likely caused by carly mobility occurring among bad job matches once these are known by both parties. Separation rates eventually decline with job tenure because the surviving matches are increasingly dominated by 'good matches".

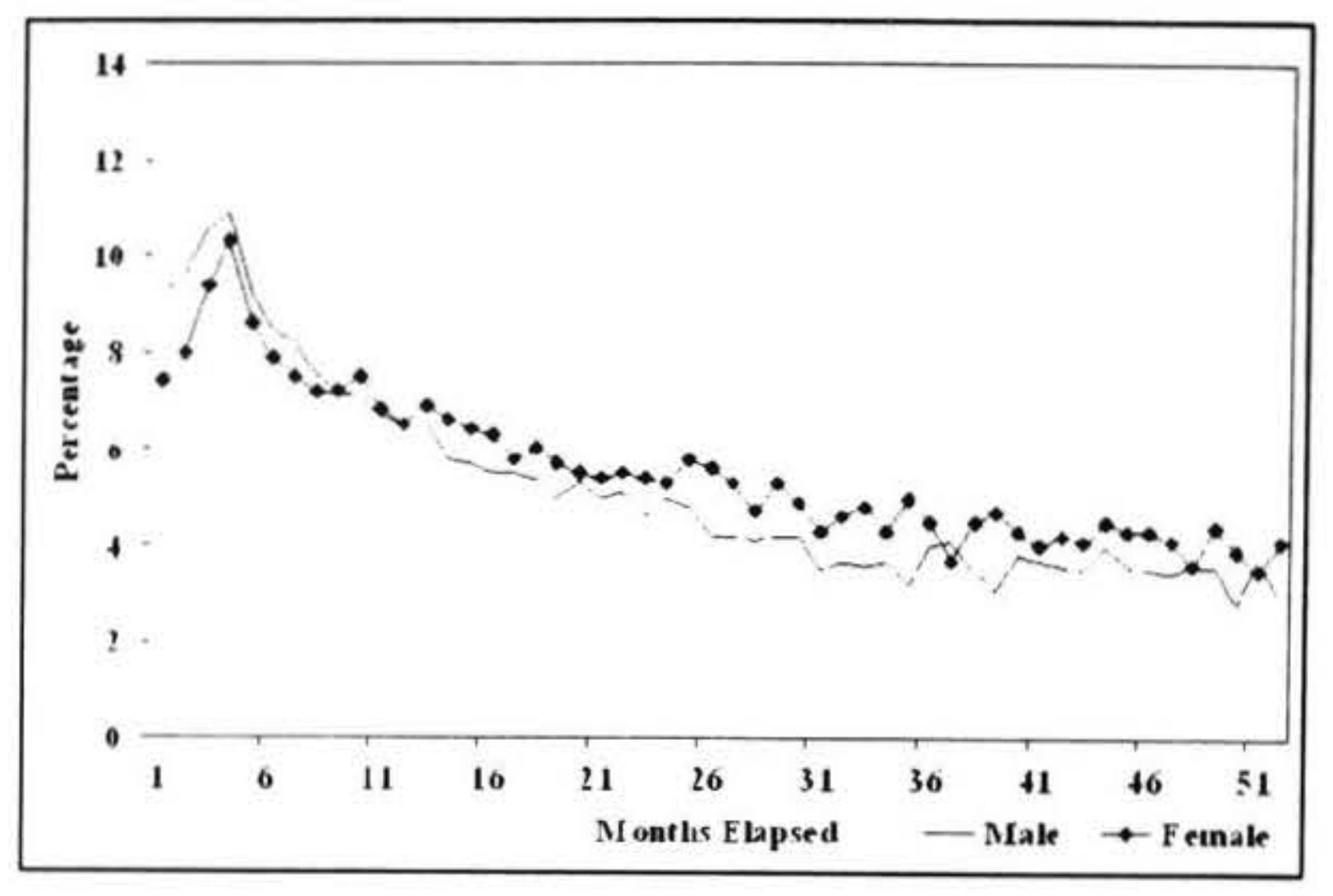

Figure I shows the estimated hazard rates separately for males and females aged between 16 and 24 . The sample sizes for computing these statistics among this youngest age group are 64,857 for males and 56,056 for females. For both genders, hazard rates increase initially once the job spell has started, peaking at over 10 percent for both groups after four months on the job. These hazard rates then fall steadily to under 4 percent a month after more than four years on the job.

The estimated hazard functions for males and females 'crossover' after nearly one year on the job. Job separation rates are initially higher for males than females, but the patterns are reversed after one year in employment. This suggests that job matches involving males are more likely to end early in the relationship.? However, if these matches survive this initial 'trial period', they are more likely to evolve into a longer-term relationship.

This same pattern between young males and females can be seen in the estimated survival rates in Figure 2. These are the estimated probabilities that a job match formed between May 1999 and April 2000 will survive for at least a certain number of months. For example, more than 90 percent of job matches survive at least one month. However, fewer than 40 percent of job matches involving young people survive for at least one year, and here the rate is slightly higher for females (37.4 percent) than for males (34.6 percent). The crossover point in terms of survival rates between males and females happens after two years in the job. Males are relatively more likely than females to remain in a job beyond two years. The probabilities of young people remaining in a job for 52 months or more are estimated to be only 6.2 percent for males and 5.0 percent for females.

Figures 3 and 4 display both the estimated hazard and survival rates for males and females between the ages of 25 and 45 . The sample sizes for computing these statistics are 130,393 for males and 108,430 for females. These findings can be contrasted with those found earlier for the younger age group. Firstly, there is no evidence of rising hazard rates for this prime working-age group over the first few months on the job. Younger workers showed evidence of increases in monthly separation rates over the 
first four months on the job. The hazard rates for these prime working-age groups decline more-or-less steadily beginning with the first month on the job. Presumably this is because the qualities of the job matches involving older workers are revealed sooner among older workers. This explanation is also consistent with the relatively lower hazard rates among this older group. Where less than $\mathbf{4 0}$ percent of males and females between the ages of 16 and 24 were likely to remain in jobs for at least one year, the same is true for more than 40 percent of males and females between the ages of 25 and 45 .

\section{Figure 2: Estimated survival rates for workers aged} 16 to 24 .

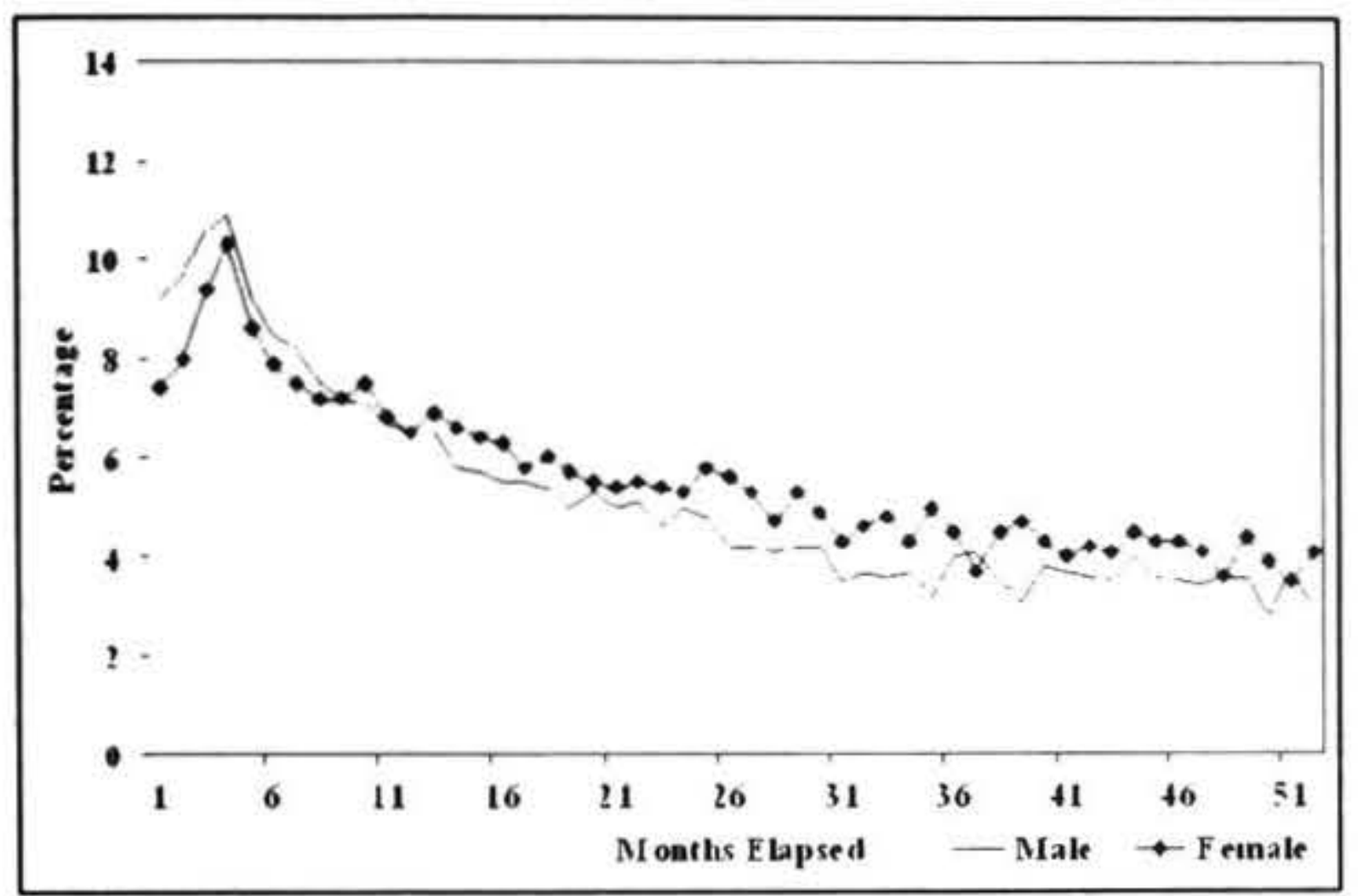

Figure 3: Estimated hazard rates for workers aged 25 to 45 .

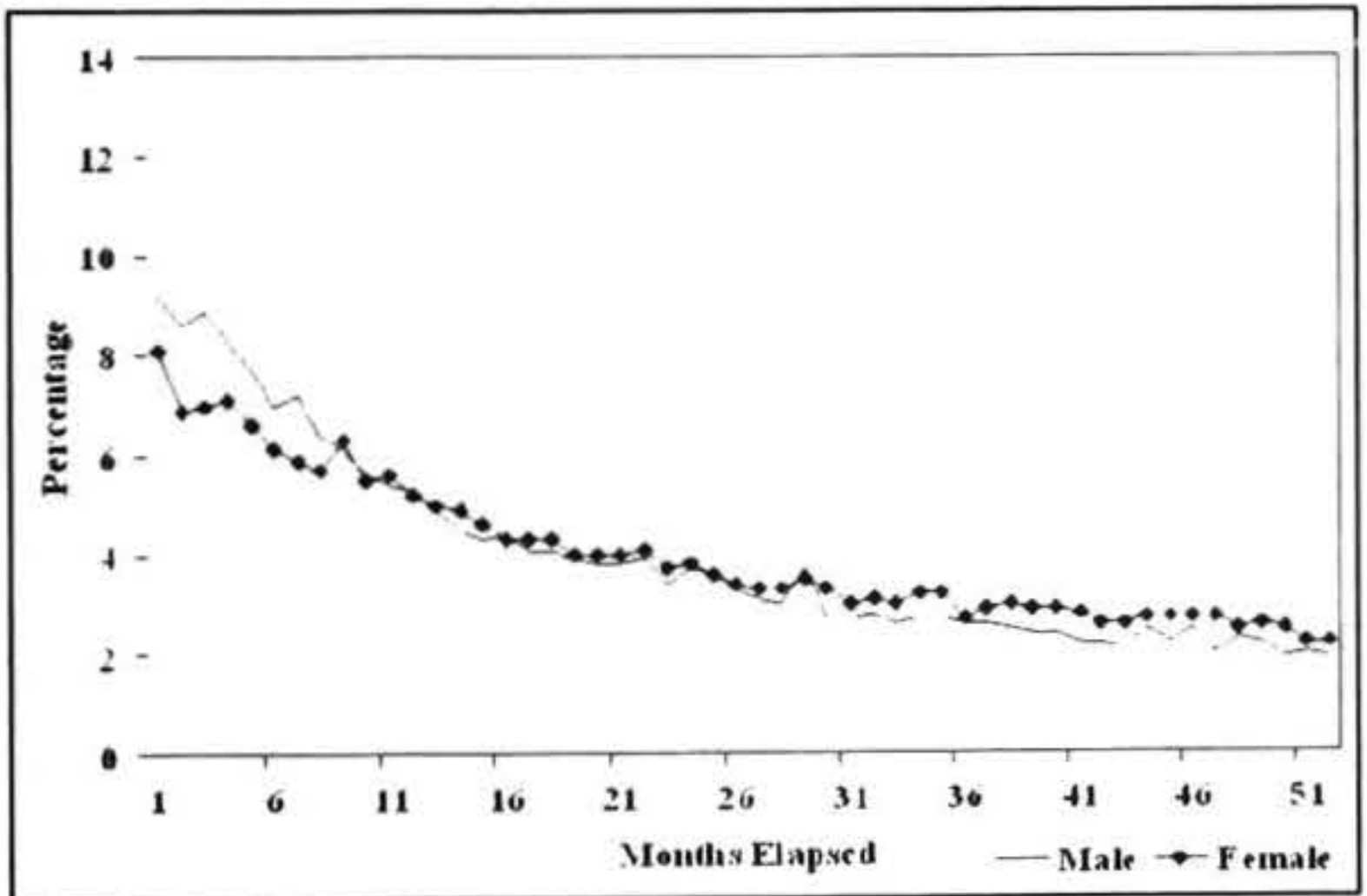

Like teenagers and young adults, however, male and female hazard rates for prime working-age individuals display a similar crossover point. Up to the first year in a job, females have lower estimated hazard rates than males among those aged between 25 and 45 . But beyond one year on the job, the hazard rates are relatively higher for women. The flatter hazard profile for women may indicate that relatively more is known about the quality of their job matches a priori, and that other life events (e.g., child birth) unrelated to match qualities may play a larger role in interrupting their employment histories. It should be noted that although survival rates are initially higher for women than men in this age group, both males and females are nearly equally likely to remain in the same job for up to 52 months (12.1 percent for males and 11.9 percent for females). Where slightly more than one-intwenty new employment spells last 52 months or more among teenagers and young adults, the same is true for more than one-in-ten employment spells involving prime working-age adults. It is important to note that the results generated thus far suggest that women do not have generally higher rates of job mobility compared to men.

Figure 4: Estimated survival rates for workers aged 25 to 45 .

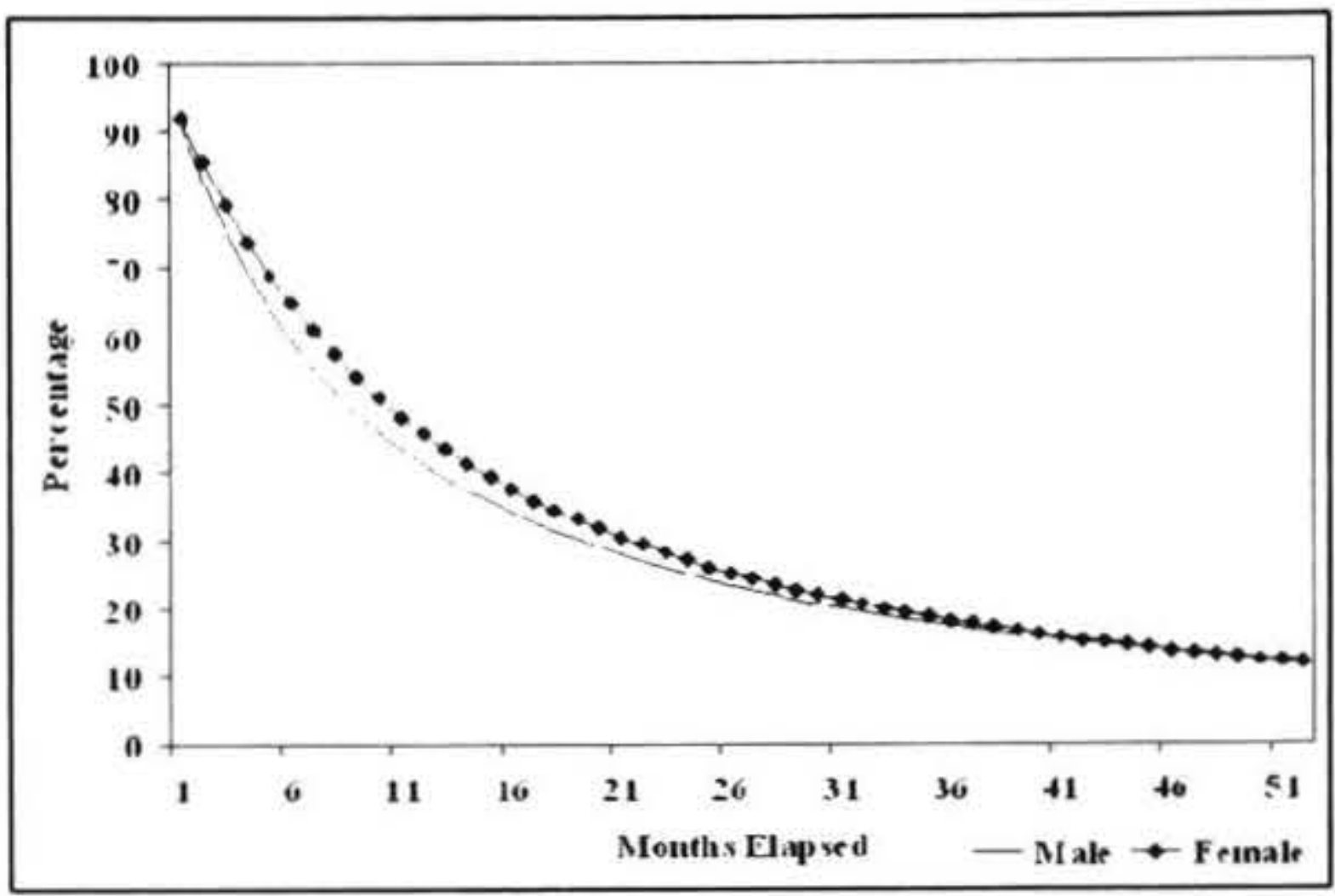

Figure 5: Estimated hazard rates for workers aged 46 to 64 .

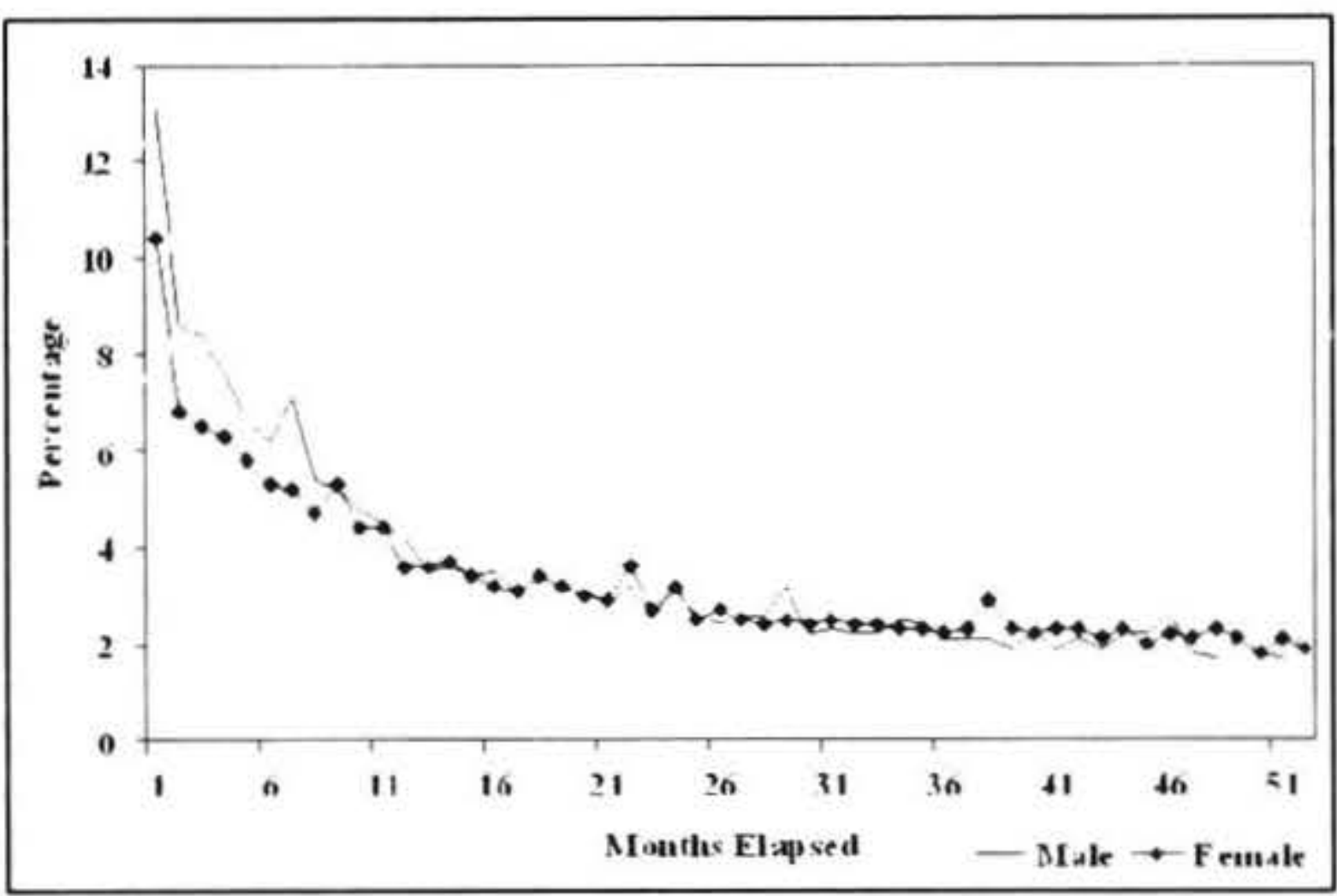

Figure 6: Estimated survival rates for workers aged 46 to 64 .

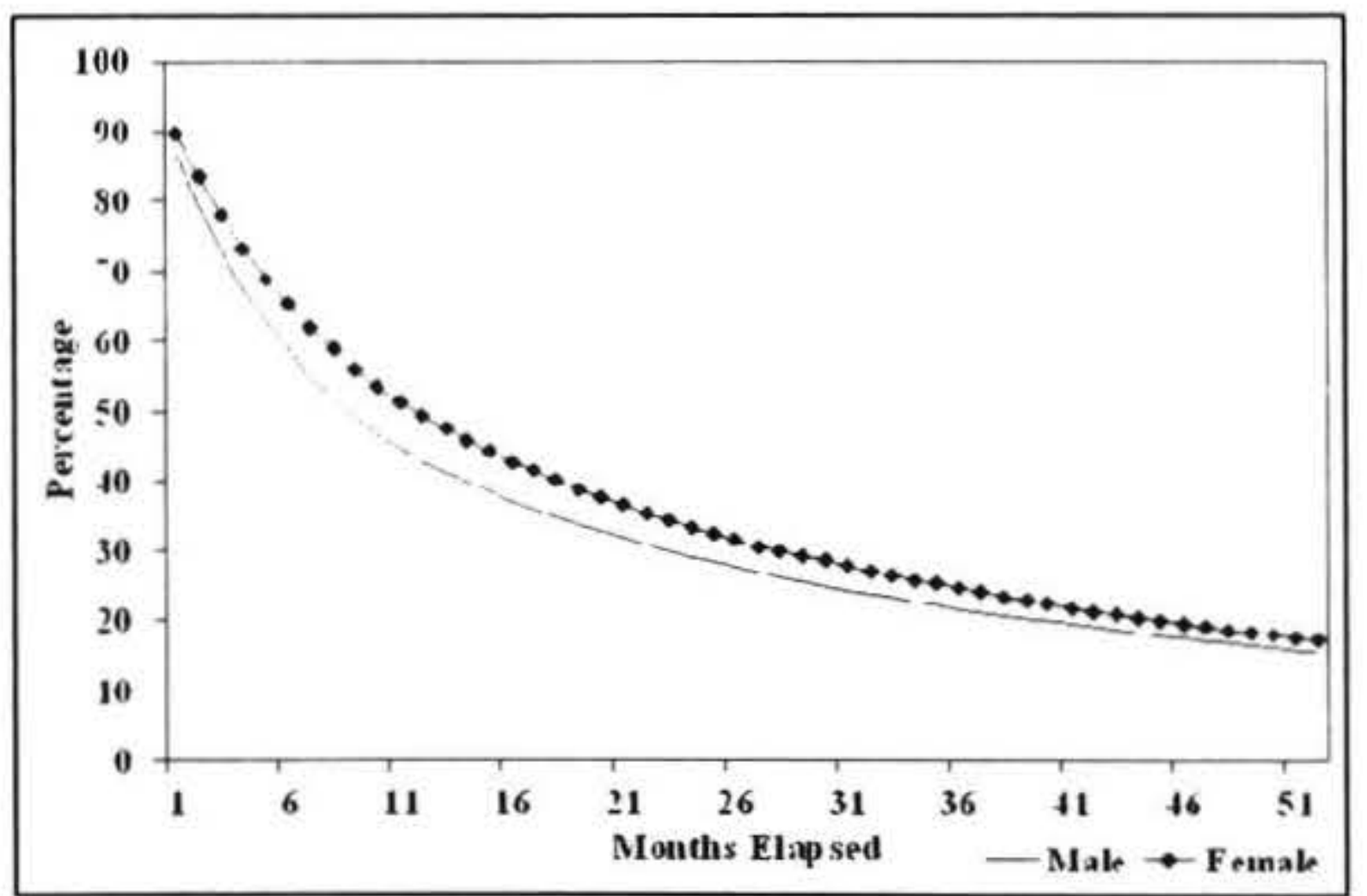


Finally, Figures 5 and 6 show the estimated hazard and survival rates for males and females between the ages of 46 and 64 . The sample sizes for computing these statistics are 35,475 for males and 28,990 for females. The decline in the hazard rate for this older-age group is more pronounced initially than that of the prime workingaged group shown earlier. It falls from an initial monthly rate of more than 10 percent for both males and females to eventual monthly rates of around 2 percent beyond two years on the job. This short-term job churning may be an artefact of individuals approaching the end of their working lives when long-term employment relationships have already ended. Remember that these patterns of labour market churning are computed fer jobs that only began between May 1999 and April 2000. Thus, they ignore any jobs that commenced prior to May 1999.

The relationship of hazard and survival rates between older males and females is somewhat different from what we've already seen earlier among younger workers. Like the two previous age groups, females have lower estimated hazard rates than males over the first year on the job. These gender differences, however, are larger than those found earlier. Moreover, this pattern is not offset by relatively higher hazard rates for females after one year on the job. The result is a uniformly higher survival profile for older women relative to older men. Once in a job after age 45, women are more likely than men to remain in that job for anytime up to 52 months. The probabilities of this oldest age group remaining in a job for 52 or more months are estimated to be 15.6 pereent for males and 17.3 percent for females. Again, this finding reinforces the previously stated conclusion that women do not display generally higher rates of job mohility compared to men.

\section{Differing Characteristics of Job Stayers and Job Changers}

This section focuses on the consequences of job mobility for the earnings received by workers. We restrict our sample to males who were between the ages of 25 and 54 as of April 1999. This means that no individual could bc older than 59 by the end of our sample period in April 2004. This age restriction eliminates some of the problems associated with job churning that may be related to combining employment with education early in life, and transitions into retirement later in life. The motivation for excluding females is to avoid observing changes in earnings that are more likely associated with changes in hours of work. Women are more likely to experience volatility in their work patterns, especially during the child-rearing years. Men are more likely to work full-time, and if they do work part-time are probably less likely to vary their work patterns over time. These age and gender restrictions should result in a sample of workers with a greater attachment to the labour foree and a higher probability of full-time work.

In addition, the sample is further restricted to individuals who have 'stable employment' over defined periods. For what we call the 'job-changing sample', each individual must have had at least one year of tenure with the same employer before a job separation, and at least one year of tenure with another employer after the intervening period between jobs (which could last for more than one year in length). We require these histories of stable employment for this job-changing sample to obtain a better picture of their earnings patterns in more enduring jobs both before and after this transition period. As a result, we ignore in this analysis any observations of workers with less stable employment histories either before or after this job change. ${ }^{x}$

To produce a relevant counterfactual group, the earnings histories of workers with at least two years of tenure with the same employer during our sample period are also produced. We refer to this as the 'job-staying sample'. The idea is that the earnings patterns over this two-year period can be compared between the samples of job changers (our experimental group) and job stayers (our control group). We ask, for example, whether or not job changers experience either an absolute or relative drop in their earnings trajectories with their job transitions. Do earnings tend to grow at a slower or faster rate after a job change? Are these differences related to either the time interval between jobs or other observable characteristics of either workers or firms? ${ }^{9}$

Table 3 reports some descriptive statistics from the jobchanging and job-staying samples. The numbers of observations are reported in the bottom row of this table. There are a total of 104,327 prime-aged males in our database who changed jobs, and spent at least a full year with one employer immediately before this job transition, and a full year with another employer after this transition. There are a total of 293,568 prime-aged males who stayed in the same job for at least two consecutive years. The final two columns of Table 3 split the job-changing sample into those with initially low and high earnings in this first period. The suspicion is that the impacts of a job change on earnings may be quite different depending on the initial earnings of the individual. The job-changing sample was split between individuals with mean monthly carnings in the first period either below or above median earnings in this sample.

Workers who didn't change jobs were, on average, older than those who did change jobs ( 38.8 years vs. 37.2 years of age at the start of the first period). Among those who did change jobs, the average worker with initial earnings above the sample median was more than one year older than the average worker with initial earnings below the sample median. Yet, job changers with high initial earnings were still more than a full year younger (37.7 years) than those who didn't change jobs ( 38.8 years).

Individuals who stayed in their jobs tended to work for larger firms (with medians of 104 and 109 employees in the first and second periods, respectively) relative to individuals who changed jobs (with medians of 69 and 71 employees in the two periods). ${ }^{10}$ Job changers with initially low carnings tend to start out in smaller firms, but move to larger firms (an increase from 32 to 39 employees). Job changers with initially high earnings tend to start out in larger firms, but move to smaller firms (a decline from 161 to 143 employees). 
Mean real monthly earnings are higher for job stayers than job changers in both periods." earnings of job stayers increased between the two periods by 4.8 percent, the average earnings of job changers increased by 5.9 percent. $^{12}$ This resulted in a narrowing of the earnings gap between the two groups. For example, the average earnings of job changers were 98.5 percent of their non-changing counterparts during the first twelve months $(\$ 3,705.40$ divided by $\$ 3,761.26)$. This gap narrowed to 99.5 percent between the same groups in the second twelve months $(\$ 3,922.40$ divided by $\$ 3,942.90$ ). Yet, it is important to note that this slightly higher growth rate in earnings is not equally distributed across those who change jobs. Those with initially low earnings experienced an average earnings growth of 11.0 percent, while those with initially high earnings had only a 2.2 percent growth in earnings between periods. Although the average job changer experiences a faster growth rate in earnings, the results vary substantially across this group relative to their initial earnings.

Table 3 also shows that changes in earnings between periods are relatively more volatile for the job-changing sample. Slightly less than two-thirds (65.2 percent) of job stayers experienced an increase in real earnings between periods. A smaller proportion of job changers (61.8 percent) experienced an increase in real earnings between periods. For those experiencing a growth in earnings, however, the average size of this increase was substantially larger for job changers ( 12.4 percent) than for job stayers ( 7.0 percent). For those experiencing a decline in earnings, the average size of the decrease for job changers ( -6.6 percent) was thee-times larger than that occurring among job stayers (-2.2 percent).

Within the job-changing sample, those with initially low earnings were much more likely to experience an increase in earnings ( 68.6 percent) compared to those with initially high earnings ( 54.9 percent). These increases in earnings were much larger in magnitude for those with initially low earnings ( 17.2 percent) relative to those with initially high earnings ( 9.7 percent). Among job-changers who experienced a drop in earnings, the magnitude of these declines were smaller for those with initially low earnings ( -4.9 percent) relative to those with initially high earnings (-7.4 percent).

Table 3: Descriptive statistics on job stayers and job changers from LEED database.

\begin{tabular}{|c|c|c|c|c|}
\hline \multirow[b]{2}{*}{ Variables: } & \multirow[b]{2}{*}{$\begin{array}{c}\text { Job } \\
\text { Stayers }\end{array}$} & \multirow[b]{2}{*}{$\begin{array}{c}\text { Entire } \\
\text { Subsample }\end{array}$} & \multicolumn{2}{|c|}{ Job Changers: } \\
\hline & & & $\begin{array}{l}\text { Low Initial } \\
\text { Earnings }\end{array}$ & $\begin{array}{c}\text { High Initial } \\
\text { Earnings }\end{array}$ \\
\hline Mean Age at Start of $1^{\text {st }}$ Period & 38.8 & 37.2 & 36.6 & 37.7 \\
\hline $1^{\text {st }}$ Period - Median Number of Employees in Firm & 104 & 69 & 32 & 161 \\
\hline $2^{\text {nd }}$ Period - Median Number of Employees in Firm & 109 & 71 & 39 & 143 \\
\hline $1^{\text {st }}$ Period - Mean Monthly Real Earnings for Worker & $\$ 3,761.26$ & $\$ 3,705.40$ & $\$ 2,637.83$ & $\$ 4,772.98$ \\
\hline $2^{\text {nd }}$ Period - Mean Monthly Real Earnings for Worker & $\$ 3,942.90$ & $\$ 3,922.20$ & $\$ 2,962.29$ & $\$ 4,882.13$ \\
\hline$\% \Delta$ in Real Earnings & $4.8 \%$ & $5.9 \%$ & $11.0 \%$ & $2.2 \%$ \\
\hline Proportion Receiving an Increase in Earnings & $65.2 \%$ & $61.8 \%$ & $68.6 \%$ & $54.9 \%$ \\
\hline$\% \Delta$ in Earnings for those Receiving an Increase & $7.0 \%$ & $12.4 \%$ & $17.2 \%$ & $9.7 \%$ \\
\hline Proportion Receiving an Decrease in Earnings & $34.8 \%$ & $38.2 \%$ & $31.4 \%$ & $45.1 \%$ \\
\hline$\% \Delta$ in Earnings for those Receiving a Decrease & $-2.2 \%$ & $-6.6 \%$ & $-4.9 \%$ & $-7.4 \%$ \\
\hline $1^{\text {st }}$ Period - Mean Monthly Real Earnings for Firm & $\$ 2,613.18$ & $\$ 2,809.82$ & $\$ 2,413.58$ & $\$ 3,506.94$ \\
\hline $2^{\text {nd }}$ Period - Mean Monthly Real Earnings for Firm & $\$ 2,635.33$ & $\$ 3,089.18$ & $\$ 2,784.49$ & $\$ 3,625.23$ \\
\hline$\% \Delta$ in Real Earnings & $0.8 \%$ & $9.9 \%$ & $15.4 \%$ & $3.4 \%$ \\
\hline $1^{\text {st }}$ Period - Mean Monthly Real Earnings for Industry & $\$ 3,390.58$ & $\$ 3,361.95$ & $\$ 3,283.85$ & $\$ 3,440.05$ \\
\hline $2^{\text {nd }}$ Period - Mean Monthly Real Earnings for Industry & $\$ 3,331.22$ & $\$ 3,473.88$ & $\$ 3,464.62$ & $\$ 3,483.15$ \\
\hline$\% \Delta$ in Real Earnings & $-1.8 \%$ & $3.3 \%$ & $5.5 \%$ & $1.3 \%$ \\
\hline$\%$ with Job Transition $\leq 1$ Month & --. & $87.5 \%$ & $86.4 \%$ & $88.6 \%$ \\
\hline$\%$ with Job Transition $>1$ Month and $\leq 3$ Months & --- & $5.6 \%$ & $6.1 \%$ & $5.1 \%$ \\
\hline$\%$ with Job Transition $>3$ Month and $\leq 6$ Months & --- & $2.7 \%$ & $2.9 \%$ & $2.4 \%$ \\
\hline$\%$ with Job Transition $>6$ Month and $\leq 12$ Months & $--\cdot$ & $2.2 \%$ & $2.5 \%$ & $1.9 \%$ \\
\hline$\%$ with Job Transition $>12$ Months & --- & $2.0 \%$ & $2.0 \%$ & $2.0 \%$ \\
\hline Number of Observations & 293,568 & 104,327 & 52,164 & 52,163 \\
\hline
\end{tabular}

Notes: Data provided by Statistics New Zealand from the Linked Employer-Employee Data (LEED). The base period is January 2005 in computing real earnings using the Consumer Price Index (CPI). Workers without a job change spent at least 24 months with the same employer. Workers with a job change spent at least 12 months in the first period with one employer, and at least 12 months in the second period with another employer. The industry is the two-digit ANZSIC industry. 
It's easy to summarise these findings. Job stayers are slightly more likely than job changers to experience an increase in real earnings between periods. However, these earnings changes are substantially more varied among job changers. Job changers who experience an increase in earnings do relatively better if they have low earnings in the first period, while those who experience a decrease in earnings do relatively worse if they have high earnings in the first period. Thus, there is evidence of 'mean reversion' in the earnings of job changers.

Table 3 also shows what is happening at both the firm and industry level. The average real earnings paid by firms in which job stayers were located increased by an average of only 0.8 percent between periods. The average real earnings in industries in which job stayers were employed actually fell by 1.8 percent. On the other hand, the average earnings paid by the firms and industries in which job changers were located grew by 9.9 percent and 3.3 percent, respectively. These findings suggest that job changers tend to move to both firms and industries that pay relatively higher earnings to all their workers. In other words, job changers tend to leave low-paying firms and industries in favour of high-paying firms and industries.

The firm and industry location of individuals seems to be closely related to the different experiences of job changers with initially low and high earnings. We saw earlier that that job changers with initially low earnings tend to experience substantially larger earnings increases. The average earnings paid by the firms and industries of initially low-earning job changers grew between periods by 15.4 and 5.5 percent, respectively. Similarly, the lack of growth in individual earnings for those with initially high earnings is tied to fact that they are unwilling or unable to move to these high-paying sectors (at least partly attributable to the observation that they are already working in high-paying firms and industries). The average earnings paid by firms and industries of initially high-earnings job changers increased between periods by 3.4 percent and 1.3 percent, respectively.

Finally, Table 3 shows the time intervals between jobs experienced by those in job-changing sample. The vast majority of job changers ( 87.5 percent) spent one month or less between jobs, and these short time intervals were more common among those with initially high earnings (88.6 percent) compared to those with initially low earnings ( 86.5 percent). At the other end of the spectrum, only 2 percent of job changers spent more than one year between jobs.

\section{Differing Earnings Trajectories of Job Stayers and Job Changers}

We know from descriptive statistics reported in Table 3 that job changers, on average, experience a larger growth rate in earnings between periods compared to job stayers. For this reason, we look more carefully at the earnings histories of both job stayers and job changers in this section. We do this by plotting the monthly real earnings figures for both groups, and further divide the results for job changers by both their initial earnings and the time interval spent between jobs. These results are displayed in Figures 7 through 12.

A particular feature of these data should be made clear at the outset. The original intention of this project was to compare 24 months of earnings histories of both job stayers and job changers. Although both groups must have been in one or two jobs over this number of months, it was not realised until later that the first month in a job did not provide the intended information on normal, monthly earnings. This was because the individual could have started the job anytime during the first calendar month. As a result, average earnings reported for the first month reflect less than normal monthly earnings. To keep the earnings histories comparable, we simply exclude the earnings from the first month in a job in constructing these profiles. Other problems were encountered in putting together the data on earnings in the last month of the second period. For these reasons, the earnings histories for job stayers are taken over 22 months in that job, while the earnings histories for job changers are taken over 21 months ( 11 months in the first job and 10 month in the second job).

The average earnings histories of job changers and job stayers are shown in Figure 7. The earnings profile for job stayers is displayed in blue, while the profiles for job changers are purple for the first job and green for the second job. The narrowing of the earnings gap between job stayers and job changers is apparent in these profiles. It comes from two distinct sources. Firstly, the job change appears to be associated with a slight upward shift in the earnings trajectories for this group. This is equivalent to an increase in the vertical intercept in the earnings profile. Secondly, the growth rate in earnings over the final tenmonth period is slightly higher for job changers than for job stayers. This is equivalent to a steeper slope in the earnings profile. However, this steeper slope in the carnings profile of job changers appears to predate this job transition. The combination of a slight upward shift in the vertical intercept and steeper earnings profile results in the elimination in the earnings gap between job stayers and job changers by the end of the second period.

Figure 7: Mean real earnings profiles for job stayers and job changers.

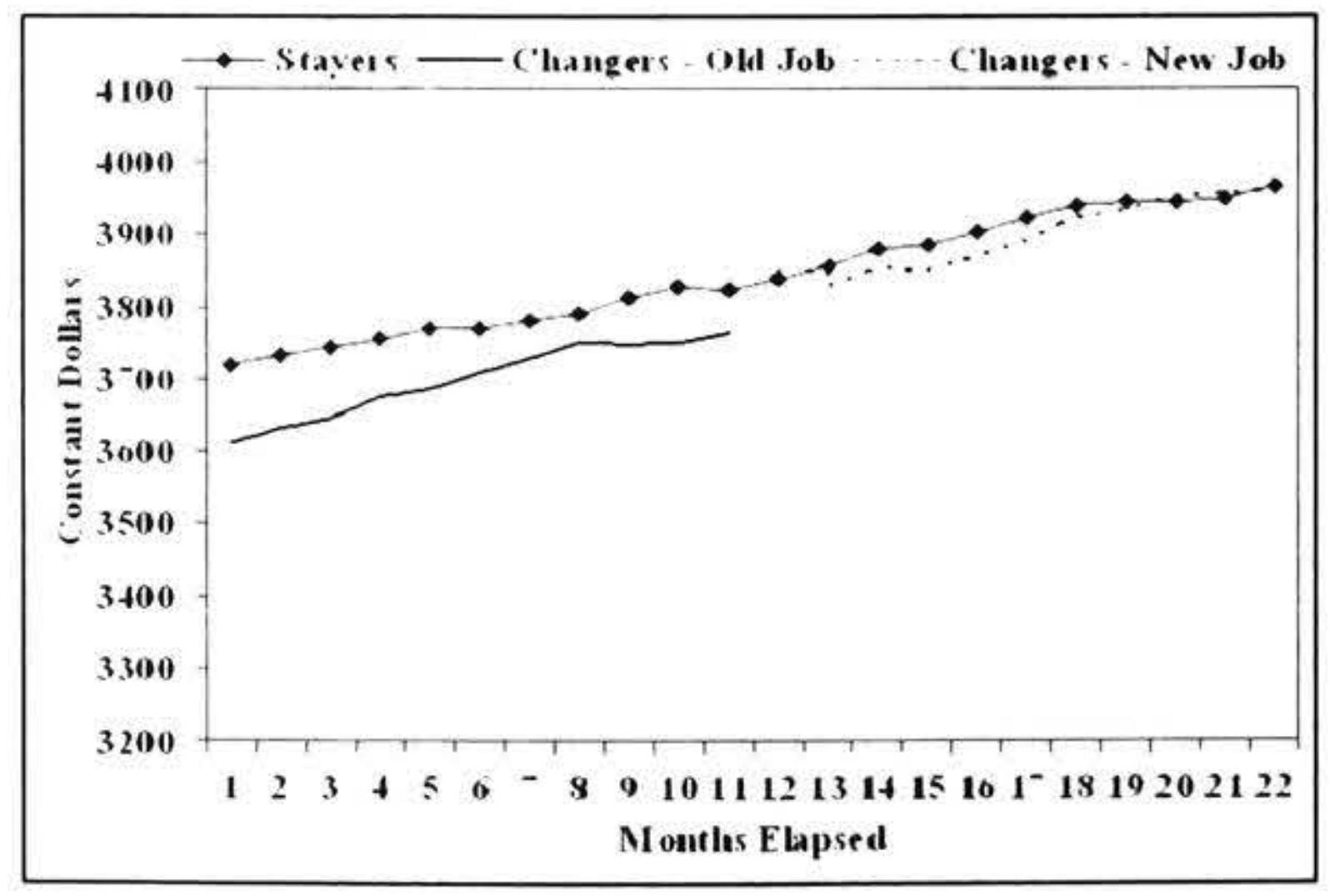


Figure 8 compares the separate earnings profiles for job changers who are initially above and below median earnings to the same counterfactual earnings trajectory for job stayers. ${ }^{13}$ The reason for the different earnings results in the second period for job changers shown in Figure 7 is immediately obvious. Where the job change appears to result in a substantial increase in the vertical intercept for the average earnings profile of initially low-earning individuals, it slightly decreases the vertical intercept for initially high-earning individuals. Thus, a key to the narrowing of the overall earnings profiles between job stayers and job changers is the increase in the starting earnings in the new job among low initial earners in the latter group.

Figure 8: Mean real earnings profiles for job stayers and job changers (below and above median earnings).

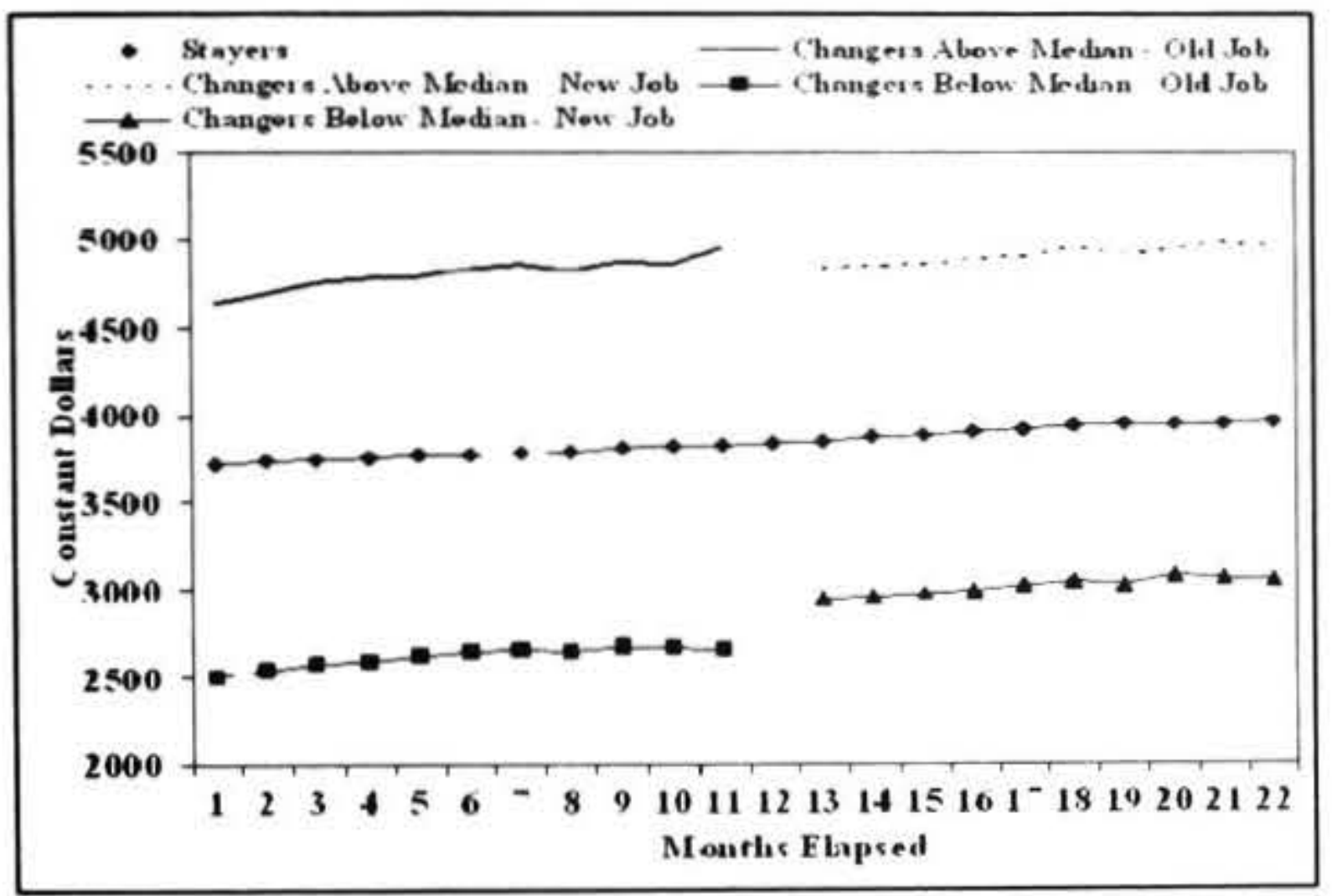

Figure 9: Mean real earnings profiles for job stayers and job changers (job transition one month or less).

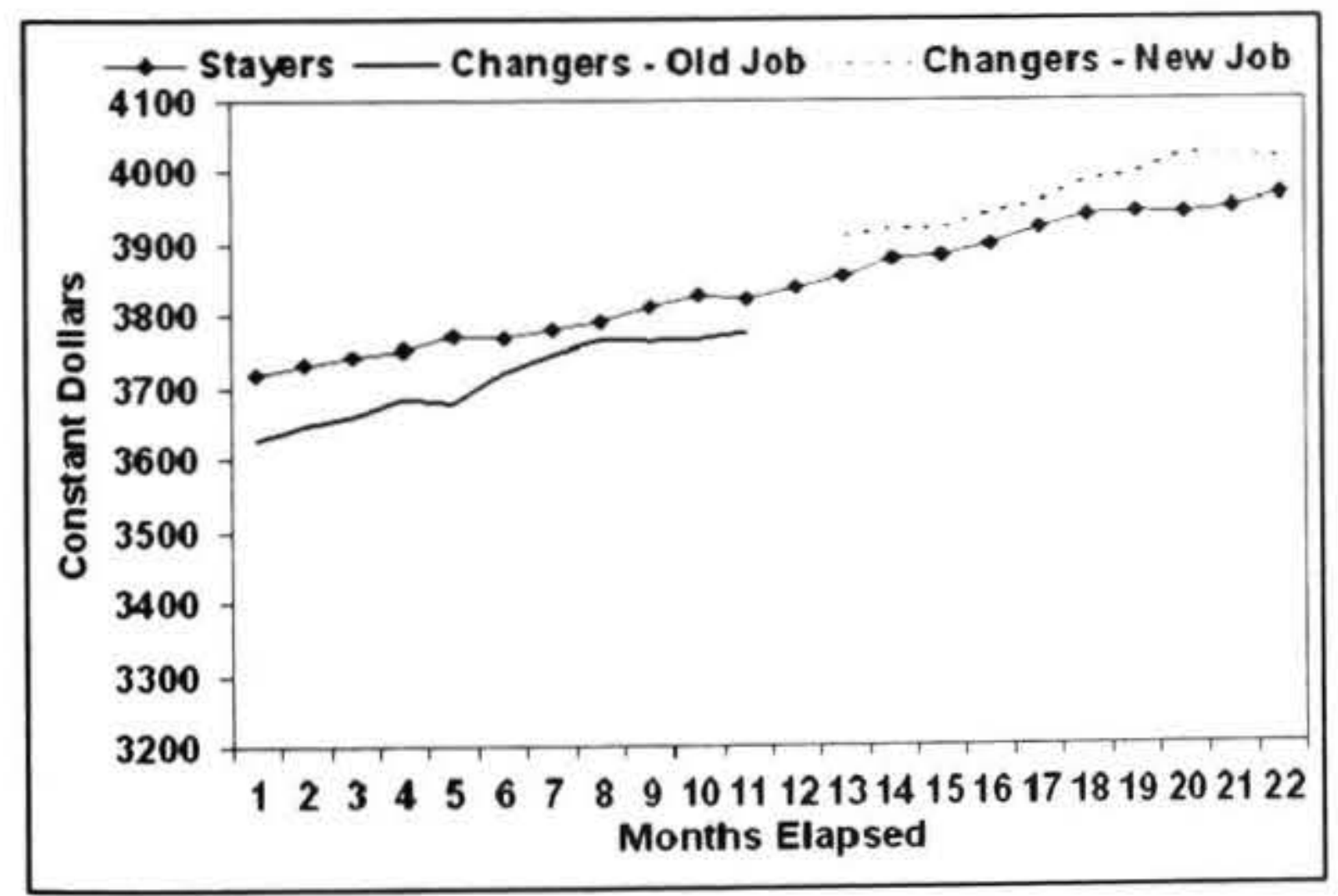

The same two-figure analysis is repeated for the jobchanging sample by the length of time interval between jobs. In each case, the earnings profile for the job-staying sample remains the same. Recall from Table 3 that the vast majority of job changers ( 87.5 percent $)$ spent one month or less between jobs. Figure 9 shows that their earnings profile in the first period was consistently below that of job stayers. Yet, their earnings profile in the second period was consistently above that of job stayers. The increase in the vertical intercept of the earnings profile for job changers experiencing a short transition period is more than enough to have them 'overtake' the earnings profile of job stayers.

Figure 10 shows the average earnings profiles for job changers experiencing a short transition period for those who had earnings in the initial period either above or below median earnings in the sample. The high-earning group does not suffer the reduction in the vertical intercept we had seen earlier in Figure 8 for all job changers. Their earnings profile over the entire sample period looks very similar to that of the job-staying sample (albeit with a higher vertical intercept). However, the low-earning group of job changers experienced a substantial increase in the vertical intercept of their earnings profile after they change jobs. For those with a short transition period, high-earning job changers do no worse, while low-earning job changers do much better in terms of earnings trajectories relative to their job-staying counterparts. Short transitions allow workers to escape low-earning jobs.

Figure 10: Mean real earnings profiles for job stayers and job changers (below and above median earnings job transition one month or less)

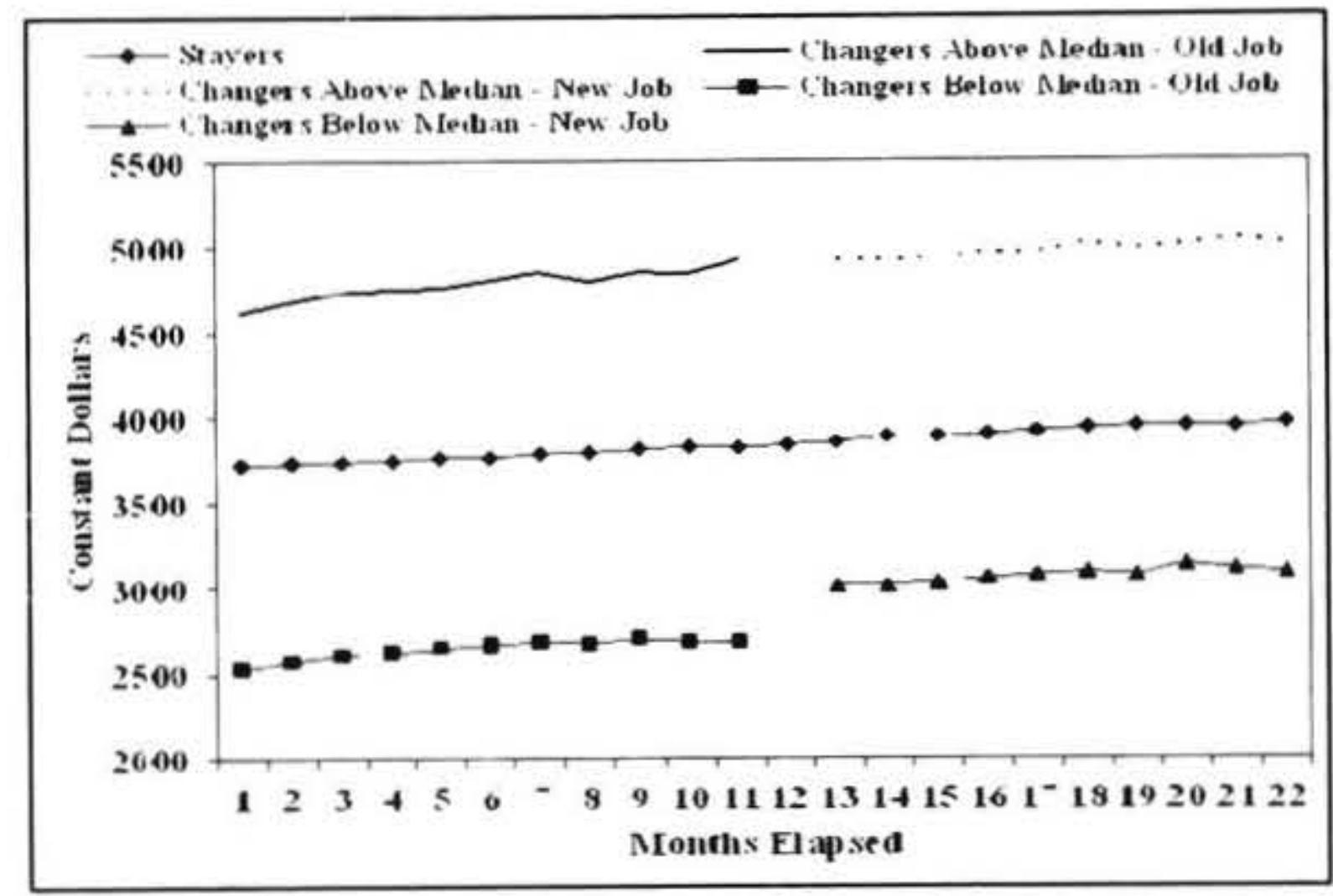

Figures 11 and 12 show the earnings profiles for job changers who spent more than one month between jobs. There are substantial differences between the earnings profiles of workers who change jobs with short and long transitions. Figure 9 showed that, in terms of monthly earnings, the average job changer with a short transition was able to overtake the average job stayer. Figure 11 shows that the average job changer with a long transition worsened their position relative to that of the average job stayer. These job changers saw their vertical intercept fall by over 4 percent in real earnings between periods.

Figure 12 shows the average earnings profiles for job changers experiencing a long transition period for those who had earnings in the initial period either above or below median earnings. The low-earning group does not substantially improve their earnings position relative to that of job stayers in the second period. Their earnings profile over the entire sample period looks very similar to that of the job-staying sample (albeit with a lower vertical intercept). However, the high-earning group of job changers experienced a substantial decrease in the vertical intercept of their earnings profile after they change jobs. 
For those with a long transition period, low-earning job changers do no better, while high-earning job changers do much worse in terms of earnings relative to their jobstaying counterparts. For those in high-earning jobs, long transitions seem to be associated with a substantial loss in earnings.

Figure 11: Mean real earnings profiles for job stayers and job changers (job transition more than one month).

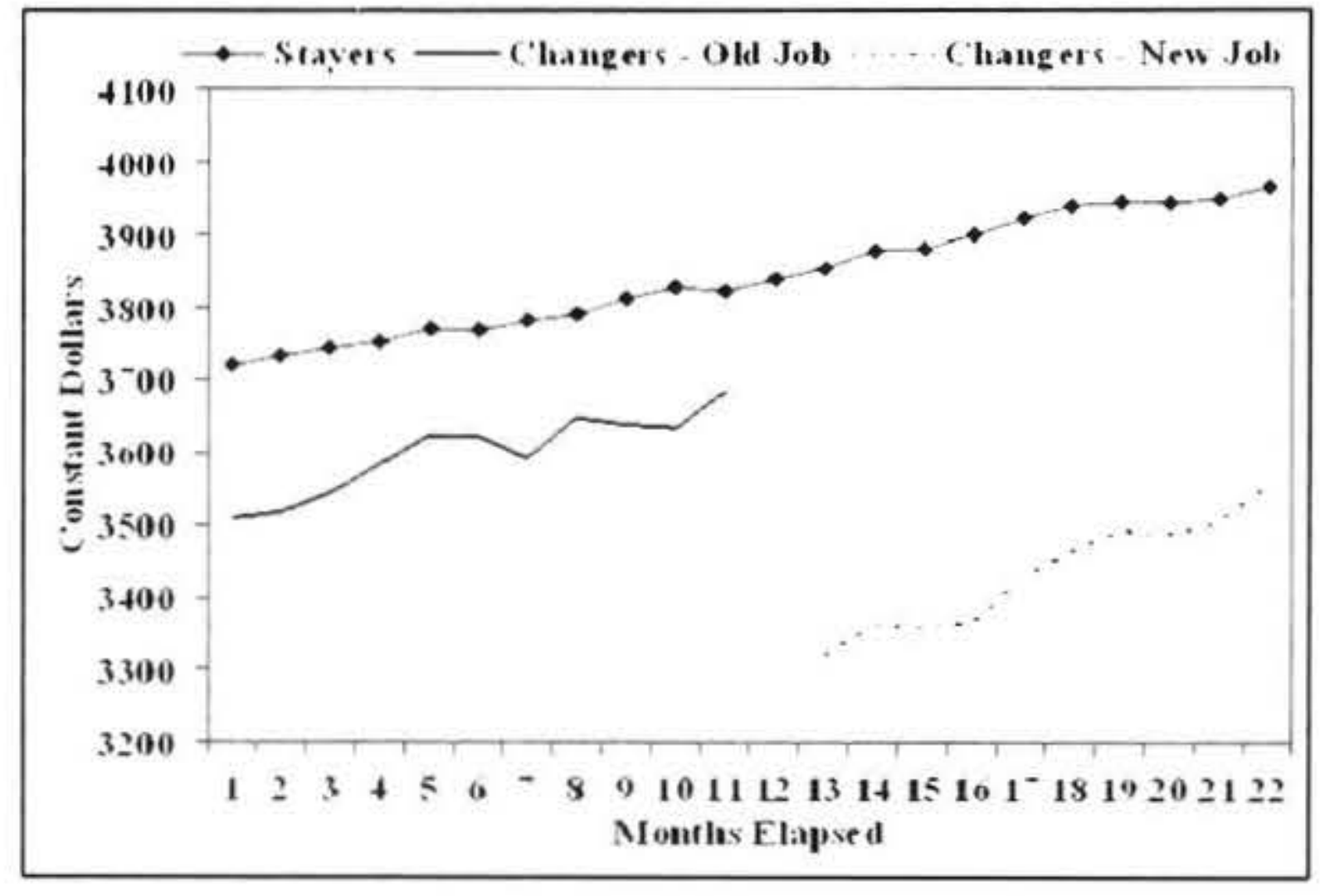

Figure 12: Mean real earnings profiles for job stayers and job changers (below and above median earnings job transition more than one month).

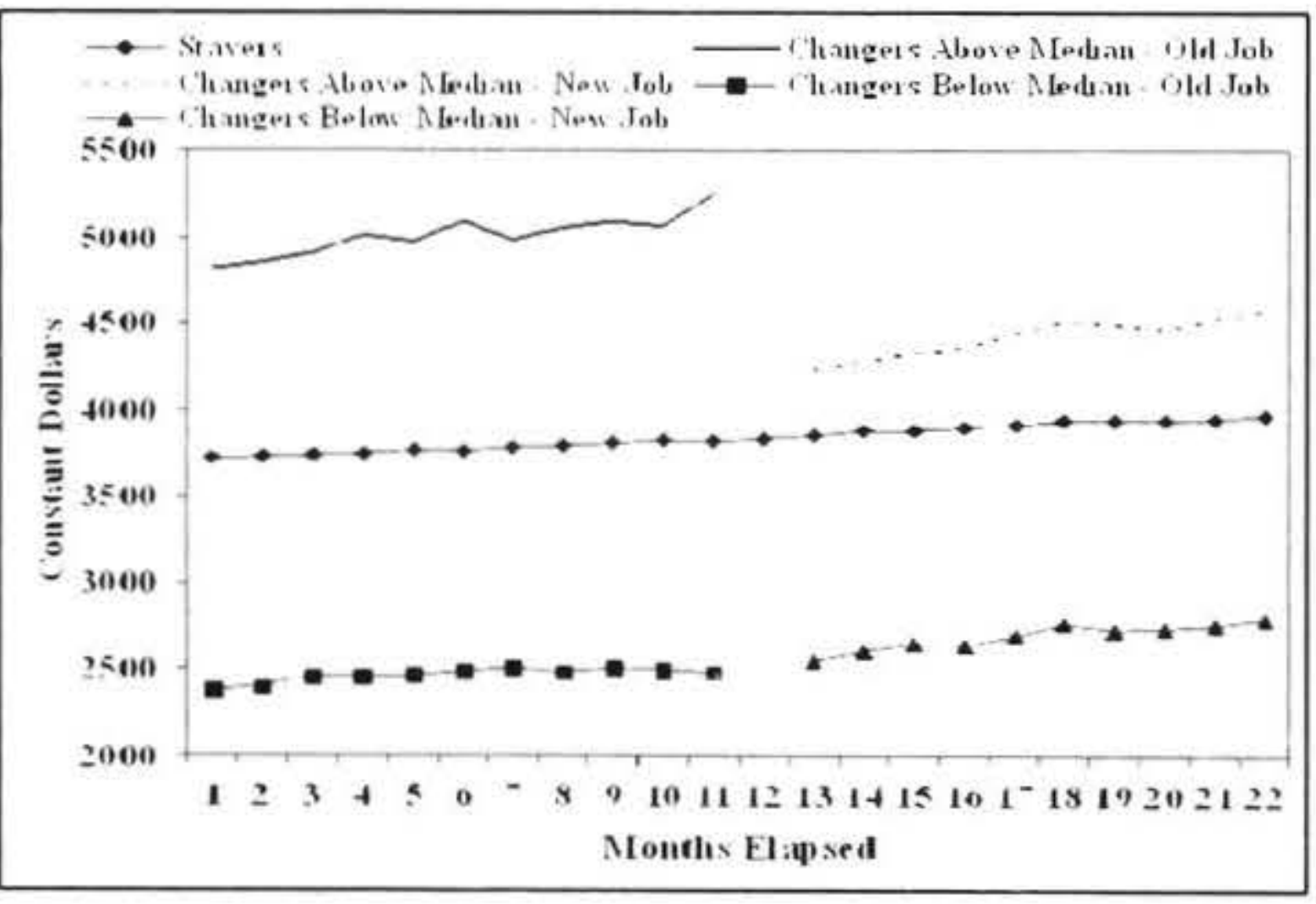

\section{Regression Analyses on the Link Between Job Mobility and Earnings}

The descriptive statisties in the previous section point to a complex relationship between job mobility and earnings. Job stayers generally receive higher earnings than job changers. Yet, on average, this earnings gap narrows with a job change once the individual is in a new job that lasts for at least one year. However, this relative growth in earnings among job changers is not uniform, and appears to be concentrated among those with relatively short job transitions and, more importantly, those receiving initially low earnings. It is possible, of course, that changes in real earnings for both job stayers and job changers may be related to other observable factors. For this reason, we turn to regression analysis in this section.
A simple regression specification is used to estimate the partial effects of job mobility on earnings growth. This specification is adapted from the one used by Holzer et al. (2004). The dependent variable is the difference in the natural logarithms of mean real monthly earnings between the two observed periods for the individual. The result can be interpreted as the growth rate in average real earnings between the two periods. ${ }^{14}$ This change in the natural logarithm of earnings is regressed against a set of independent variables contained in the vector $X_{i}$ (see Equation ( 1 ) below). We add variables to this list of regressors in an effort to see how sensitive the key coefficient estimates are to the inclusion of other covariates. These independent variables include personal, firm and industry-level characteristics.

$$
\Delta \ln \left(\operatorname{Earn}_{i}\right)=X_{i}^{\prime} \beta+u_{i}
$$

Table 4 reports the results from four different specifications of this earnings growth equation. There are 397,895 individual observations in this estimation. The first specification includes only a constant term and a dummy variable for a job change. The implicit assumption is that all individuals are identical except for the effect of a job change on the growth in earnings between periods. The estimated coefficient on this dummy variable is 0.002 , and it's statistically different from zero at better than a 5 percent level. These results suggest that the average growth in mean real monthly earnings between periods is only 0.2 percentage points higher for job changers. Recall from Table 3 that the growth rate in mean real monthly earnings was 1.1 percentage points higher for job changers compared to job stayers. These differences must be due to the way in which these growth rates are computed. The descriptive statistics in Table 3 are based on the percentage change in mean earnings between periods for each group, while the regression results are based on the individual difference in the log of mean earnings between periods.

The second regression specification listed in Table 4 includes a number of additional explanatory variables. Note that the overall explanatory power of this model increases substantially. The $R^{2}$ statistic in specification (1) says that less than 0.1 percent of the variation in the growth rate in earnings between periods can be explained by job mobility alone. The $R^{2}$ statistic in specification (2) says that 13.0 pereent of the variation in the growth rate in earnings between periods can be explained by the regressors in this model.

The inclusion of age and age squared in this regression on the change in earnings implies a cubic age-earnings profile, ${ }^{15}$ The estimated coefficients on age and age squared are negative and positive, respectively, and both are significantly different from zero at better than a one percent level. This suggests that earnings growth declines non-linearly with age. 
Table 4: Ordinary least-squares regression results - Entire sample dependent variable: Difference in individual log mean earnings between periods.

\begin{tabular}{|c|c|c|c|c|}
\hline \multirow[b]{2}{*}{ Independent Variables: } & \multicolumn{4}{|c|}{ Specification: } \\
\hline & (1) & (2) & (3) & (4) \\
\hline Constant & $\begin{array}{l}0.043^{\circ 00} \\
(0.000)\end{array}$ & $\begin{array}{l}0.124^{.00} \\
(0.008)\end{array}$ & $\begin{array}{l}0.341^{* 0} \\
(0.010)\end{array}$ & $\begin{array}{c}0.360^{\circ *} \\
(0.010)\end{array}$ \\
\hline Dummy Variable for Job Change & $\begin{array}{c}0.002{ }^{*} \\
(0.001)\end{array}$ & $\begin{array}{l}-0.005 \cdots \\
(0.001)\end{array}$ & $\begin{array}{l}-0.005 \cdots \\
(0.001)\end{array}$ & $\begin{array}{l}-0.003^{\cdots} \\
(0.001)\end{array}$ \\
\hline Age/10 & --- & $\begin{array}{l}-0.046 \cdots \\
(0.004)\end{array}$ & $\begin{array}{l}-0.034 \cdots \\
(0.004)\end{array}$ & $\begin{array}{l}-0.036 \\
(0.004)\end{array}$ \\
\hline$(\text { Age } / 10)^{2}$ & --. & $\begin{array}{c}0.004 \cdots \\
(0.000)\end{array}$ & $\begin{array}{c}0.003 \cdots \\
(0.000)\end{array}$ & $\begin{array}{c}0.003 \cdots \\
(0.000)\end{array}$ \\
\hline$\Delta$ Firm Log Mean Earnings between Periods & --- & $\begin{array}{c}0.340^{\cdots} \\
(0.002)\end{array}$ & $\begin{array}{c}0.335^{\cdots} \\
(0.002)\end{array}$ & $\begin{array}{c}0.332 \cdots \\
(0.002)\end{array}$ \\
\hline$\Delta$ Firm Mean Employees between Periods & $\cdots$ & $\begin{array}{c}0.002 \cdots \\
(0.000)\end{array}$ & $\begin{array}{c}0.002 \cdots \\
(0.000)\end{array}$ & $\begin{array}{c}0.002 \cdots \\
(0.000)\end{array}$ \\
\hline$\Delta$ Industry Log Mean Earnings between Periods & --- & $\begin{array}{c}-0.012 \\
(0.007)\end{array}$ & $\begin{array}{l}-0.018^{\circ} \\
(0.007)\end{array}$ & $\begin{array}{c}-0.009 \\
(0.007)\end{array}$ \\
\hline Index for Start of First Period & --- & $\begin{array}{c}0.015 \cdots \\
(0.000)\end{array}$ & $\begin{array}{c}0.014 \cdots \\
(0.000)\end{array}$ & $\begin{array}{c}0.013 \cdots \\
(0.000)\end{array}$ \\
\hline Job Tenure at Start of First Period & $\cdots$ & $\begin{array}{c}0.004 \cdots \\
(0.000)\end{array}$ & $\begin{array}{c}0.006 \cdots \\
(0.000)\end{array}$ & $\begin{array}{c}0.005{ }^{\cdots} \\
(0.000)\end{array}$ \\
\hline Individual Log Mean Earnings in First Period & --- & --- & $\begin{array}{l}-0.030 \cdots \\
(0.001)\end{array}$ & $\begin{array}{l}-0.030 \\
(0.001)\end{array}$ \\
\hline Time Interval between Jobs & $\cdots$ & $\cdots$ & -- & $\begin{array}{l}-0.009 \cdots \\
(0.000)\end{array}$ \\
\hline Adjusted $R^{2}$ Statistic & 0.000 & 0.130 & 0.133 & 0.138 \\
\hline Number of Observations & & & & \\
\hline
\end{tabular}

\footnotetext{
.. Significantly different from zero at $10^{\circ}$ o level using a two-tailed test.

- Significantly different from zero at $5 \%$ level. using a two-tailed test.

... Significantly different from zero at $1 \%$ level using a two-tailed test.

Notes: Data provided by Statistics New Zealand from the Linked Employer-Employee Database (LEED). The 'Mean Firm Employees' are measured in thousands for this regression. The variable 'Index for Start of the First Period' measures in years when the first period started (April 1999 is set equal to zero). The variable 'Job Tenure at Start of First Period' measures in years the consecutive months in the job held in the first period since the start of our sample period in April 1999. The 'Interval Between Jobs' is also measured in years.
}

The most important single determinant of the growth rate in individual earnings is the growth in firm-level earnings between the two periods. The estimated coefficient is 0.340 and significant at better than a one percent level. This says that a 10 percent increase in the average real monthly earnings paid by the firm (or firms), in which the individual was employed, is associated with a 3.4 percent increase in individual earnings. On average, workers experience a higher growth in their own earnings if they remain with a firm (or switch to another firm) that pays higher earnings to all of its employees.

The number of employees in the firm has a positive and statistically significant effect on the growth rate in individual earnings. However, the magnitude of this effect is relatively small. This variable is measured in thousands of employees at the firm. Thus, an increase of one thousand employees in the firm, on average, increases the growth rate in earnings by 0.2 percentage points.

Once firm-level changes in average earnings and number of employees have been held constant, the growth rate in industry earnings between the periods has no measurable impact on the growth rate in individual earnings. The estimated coefficient on this variable is -0.012 , but it is not significantly different from zero at a 10 percent level.

Because these observed 24-month employment histories could begin anytime between April 1999 and May 2002. a time trend was included to capture any systematic changes in the growth rate in earnings over this short sample period. This index variable is measured in years, with a starting value of zero in April 1999. The estimated coefficient on this variable is 0.015 , and is statistically significant at a 1 percent level. This says that the growth rate in real earnings between periods increased by an average 1.5 percentage points per year. This is consistent with a period of relative high economic growth and a tightening labour market over this sample period.

Job tenure at the start of the first period is censored from the beginning of sample period in April 1999. This variable is measured in years, but it's computed from the number of consecutive months of employment with that firm over the observable period. The estimated coefficient on tenure is 0.004 , and is statistically significant at a 1 percent level. This suggests that, on average, each additional year of job tenure increases the growth rate in real earnings between periods by 0.4 percentage points. 
Once these other covariates have been held constant, the estimated coefficient on the dummy variable for a job change switches signs. When it was included as the only explanatory variable in this regression, it had a positive and significant impact on earnings growth. However, once these other determinants of earnings growth have been included in the model, the estimated coefficient on the job change variable becomes -0.005 , and is significantly different from zero at a 1 percent level. This says that the growth rate in earnings between periods is 0.5 percentage points lower for job chnagers compared to otherwise observationally equivalent job stayers

Two determinants of earnings growth were found to be particularly responsible for this reversal in the estimated coefficient on a job change. Firstly, the inclusion of age and age squared captures the important relationship between age and earnings growth. Younger workers are on steeper segments of the age-earnings profile, and are more likely to change jobs. Thus, the higher earnings growth rate for younger workers was inappropriately attributed to job mobility under the regression specification (1).

Secondly, including both the change in mean earnings and the number of employees in the firm (or firms) between periods captures the critical importance of firm characteristics on individual earnings. Whether or not workers change jobs, being employed by a larger, higherpaying employer directly influences the earnings of individual workers. Recall from the descriptive statistics in Table 3 that job changers are more likely to experience a substantial increase in average firm-level earnings compared to job stayers and they tend to move to firms with more employees. These related aspects of a job change are more important to this outcome than the job change itself. A job change per se does not result in faster earnings growth. It is because job changes are often coupled with the movements to larger, higher-wage employers that ultimately lead to larger increases in individual earnings.

The third regression specification in Table 4 adds a variable on individual log mean earnings in the first period. The estimated coefficient on this variable is negative, and is significant at better than a I percent level. These results suggest that a 10 percent increase in real monthly earnings in the first period is associated with an average decrease in the growth in earnings between periods of 0.3 percent. Higher initial earnings generally lead to smaller subsequent increases in individual earnings. This suggests that there is some regression toward the mean' in this process.

The inclusion of this variable on initial earnings does not substantially alter the coefficient estimates on other independent variables in this model. In particular, the estimated coefficient on a job change continues to have a negative and significant impact on carnings growth between periods.

The final regression specification reported in Table 4 adds a variable on the time interval between jobs (conditional on experiencing a job change). This variable is the effective number of years between jobs, and is defined as the number of months during this transition period divided by twelve. ${ }^{16}$ The estimated coefficient on this variable is -0.009 , and is statistically significant at better than a one percent level. This says that for each year elapsed between jobs, the growth rate in earnings declines by an average of 0.9 percentage points.

When the time interval between jobs is included in the regression, the estimated coefficient on the dummy variable for a job change declines in magnitude to -0.003 , but continues to be significantly different from zero at a 1 percent level. This says that, holding other things constant, a job change that results in no time elapsed between jobs lowers the growth rate in earnings between periods by 0.3 percentage points. Yet, a job change with a time interval of one year between jobs leads to an average decline in the growth rate in earnings of 1.2 percentage points (the sum of the estimated coefficients on a job change -0.003 and the time interval between jobs $-0.009)$. This latter result is consistent with job search theory, where individuals reduce reservation wages with the length of the search period and accept increasingly lower earnings in new jobs with the time elapsed in the search process. This finding is also consistent with depreciation in human capital that is positively related to length of time out of employment.

We can quickly summarise the regression results reported in Table 4. The final set of results listed in the last column represents our preferred specification. The introduction of the two independent variables between specifications (2) and (4) raises the explanatory power of the regression model by nearly 6.2 percent (i.e., the $R^{2}$ statistic increases from 0.130 to 0.138 ). We can separately reject the null hypotheses that the coefficients on these additional regressors are equal to zero at better than a 1 percent level. This final specification highlights the complex nature of the relationship between job mobility and earnings. On average, job changes themselves have only a small negative impact on the growth in earnings. They lead to higher individual earnings growth if the worker moves to a firm that generally pays higher earnings and has more employees. The job change also significantly reduces earnings growth as the time interval between jobs increases.

The specification of the regression models reported in Table 4 assumed implicitly that the coefficients on the vector of explanatory variables were identical between job changers and job stayers. We test this assumption by separately estimating the relevant regression specifications for these two groups. These regression results are reported in Tables 5 and 6 . Only two regression specifications are estimated for job stayers. This is because some of the original specifications are irrelevant for this group (the regression that includes the dummy variable for a job change as the only regressor, and the last model that adds the variable on the time interval between jobs).

There are a number of points to make regarding the estimated determinants of earnings growth among job 
stayers. Firstly, compared to the regression results for the entire sample, age has little impact on this earnings growth. The estimated coefficients on age and age squared are insignificant in three of the four situations. The only coefficient that is statistically different from zero is related to age in the second specification. This may be because job stayers are older and generally located on flatter segments of the age-earnings profile.

Secondly, individual growth rates in earnings between periods are more closely associated with the characteristics of the firm among job stayers. The estimated coefficients on the difference in log mean earnings and the difference in mean number of employees between periods are both positive, statistically significant and larger in magnitude than those found in the overall sample. A 10 percent growth in real mean earnings at the firm, on average, is estimated to increase individual earnings by more than 4.1 percent. This compares to a similar increase of no more than 3.4 percent in individual earnings from Table 4. An increase of one-thousand employees at the firm, on average, increases the growth rate in earnings by 0.4 percentage points. This compares to 0.2 -percentage-point increase from the same rise in the number of employees reported in Table 4. Firm characteristics appear to play a relatively larger role in the determination of individual earnings growth among job stayers.

Thirdly, job tenure is estimated to reduce the growth rate in earnings between periods. One year of tenure reduces earnings growth by at least 0.3 percentage points. This is in contrast to the positive effects on job tenure that were estimated for the entire sample (Table 4).

Finally, we had seen in Table 4 that there was some evidence of regression toward the mean in earnings between periods. The estimated coefficient on first period earnings was negative and significant. In the last column of Table 5 we find that the estimated coefficient on individual first period earnings is positive and significant at better than a 1 percent level. This result suggests that a 10 percent increase in real monthly earnings in the first period is associated with an average increase in earnings growth between periods among job stayers of 1.3 percent. We had previously found that a 10 percent increase in real monthly earnings in the first period is associated with an average decrease in earnings growth between periods among all workers of 0.3 percent. Having higher earnings in the first period tends to result in a larger increase in earnings between periods only if the worker remains in that job.

Three separate regression specifications are estimated for job changers. These results are reported in Table 6 . A few important points can be raised. Firstly, age is a relatively more important determinant of individual growth rates in earnings among job changers. The coefficients on age and age squared are consistently found to be significantly different from zero, although the estimated coefficients on these variables switch signs between the first and second specifications. The importance of age for earnings growth can be explained by job changers being located earlier on age-earnings profile where the slope is steeper.

Secondly, although individual growth rates in earnings between periods for job changers are not as closely associated with firm characteristics as those found for job stayers, the coefficients on firm-level differences in log mean earnings and differences in mean number of employees between periods are still positive and statistically significant.

Table 5: Ordinary least-squares regression results job stayers dependent variable: Difference in individual log mean earnings between periods.

\begin{tabular}{|c|c|c|}
\hline \multirow[b]{2}{*}{ Independent Variables: } & \multicolumn{2}{|c|}{ Specification: } \\
\hline & (1) & (2) \\
\hline Constant & $\begin{array}{l}0.054^{\cdots} \\
(0.007)\end{array}$ & $\begin{array}{l}-0.038^{* *} \\
(0.009)\end{array}$ \\
\hline Age/ 10 & $\begin{array}{l}-0.003 \\
(0.004)\end{array}$ & $\begin{array}{l}-0.008^{* *} \\
(0.004)\end{array}$ \\
\hline$(\mathrm{Age} / 10)^{2}$ & $\begin{array}{l}-0.000 \\
(0.000)\end{array}$ & $\begin{array}{c}0.000 \\
(0.000)\end{array}$ \\
\hline $\begin{array}{l}\Delta \text { Firm Log Mean } \\
\text { Earnings between Periods }\end{array}$ & $\begin{array}{l}0.413^{\cdots} \\
(0.003)\end{array}$ & $\begin{array}{l}0.414^{\cdots \cdot} \\
(0.003)\end{array}$ \\
\hline $\begin{array}{l}\Delta \text { Firm Mean Employees } \\
\text { between Periods }\end{array}$ & $\begin{array}{l}0.005^{\cdots} \\
(0.001)\end{array}$ & $\begin{array}{l}0.005^{\cdots} \\
(0.001)\end{array}$ \\
\hline $\begin{array}{l}\Delta \text { Industry Log Mean } \\
\text { Earnings between Periods }\end{array}$ & $\begin{array}{l}-0.036 \\
(0.030)\end{array}$ & $\begin{array}{l}-0.038 \\
(0.030)\end{array}$ \\
\hline $\begin{array}{l}\text { Index for Start of First } \\
\text { Period }\end{array}$ & $\begin{array}{l}0.004^{\cdots} \\
(0.000)\end{array}$ & $\begin{array}{l}0.004^{\cdots *} \\
(0.000)\end{array}$ \\
\hline $\begin{array}{l}\text { Job Tenure at Start of First } \\
\text { Period }\end{array}$ & $\begin{array}{l}-0.003^{\cdots} \\
(0.000)\end{array}$ & $\begin{array}{l}-0.004 \cdots \\
(0.000)\end{array}$ \\
\hline $\begin{array}{l}\text { Individual Log Mean } \\
\text { Earnings in First Period }\end{array}$ & $\cdots$ & $\begin{array}{l}0.013^{\cdots} \\
(0.001)\end{array}$ \\
\hline Adjusted $\mathrm{R}^{2}$ Statistic & 0.066 & 0.067 \\
\hline Number of Observations & \multicolumn{2}{|c|}{293,568} \\
\hline
\end{tabular}

- Significantly different from zero at $10 \%$ level using a two-tailed test.

Significantly different from zero at $5 \%$ level, using a two-tailed test.

- Significantly different from zero at $1 \%$ level using a two-tailed test.

Nutes: Data provided by Statistics New Zealand from the Linked Employer-Employee Database (LEED). The 'Mean Firm Employees' are measured in thousands for this regression. The variable Index for Start of the First Period' measures in years when the first period started (April 1999 is set equal to zero). The variable 'Job Tenure at Start of First Period ' measures in years the consecutive months in the job held in the first period since the start of our sample period in April 1999.

Thirdly, both the index for time and job tenure at the start of the first period have larger effects on the earnings growth of job changers compared to job stayers. Job changers receive relatively higher earnings growth between jobs if this occurred later in the sample period 
and if they had acquired more tenure on their first job. The first result could be explained by job changers doing relatively better than job stayers in the tighter labour market near the end of our sample period. The second result might be a proxy for voluntary job mobility. Job changers with longer tenure in the first job may be more likely to quit and take up higher paying jobs.

Table 6: Ordinary least-squares regression results job changers dependent variable: Difference in individual log mean earnings between periods.

\begin{tabular}{|c|c|c|c|}
\hline \multirow{2}{*}{$\begin{array}{l}\text { Independent } \\
\text { Variables: }\end{array}$} & \multicolumn{3}{|c|}{ Specification: } \\
\hline & (1) & $(2)$ & (3) \\
\hline Constant & $\begin{array}{l}0.118^{\cdots} \\
(0.022)\end{array}$ & $\begin{array}{l}1.208^{* *} \\
(0.027)\end{array}$ & $\begin{array}{l}1.261^{\cdots} \\
(0.026)\end{array}$ \\
\hline Age $/ 10$ & $\begin{array}{l}-0.050 \% \\
(0.011)\end{array}$ & $\begin{array}{l}0.031^{\cdots} \\
(0.011)\end{array}$ & $\begin{array}{l}0.025^{*} \\
(0.011)\end{array}$ \\
\hline$(\mathrm{Age} / 10)^{2}$ & $\begin{array}{l}0.003^{\circ} \\
(0.001)\end{array}$ & $\begin{array}{c}-0.007^{\cdots \cdot} \\
(0.001)\end{array}$ & $\begin{array}{c}-0.006 \\
(0.001)\end{array}$ \\
\hline $\begin{array}{l}\Delta \text { Firm Log Mean } \\
\text { Earnings between } \\
\text { Periods }\end{array}$ & $\begin{array}{l}0.326 \cdots \\
(0.002)\end{array}$ & $\begin{array}{l}0.299^{\cdots} \\
(0.002)\end{array}$ & $\begin{array}{l}0.295^{\cdots} \\
(0.002)\end{array}$ \\
\hline $\begin{array}{l}\Delta \text { Firm Mean } \\
\text { Employees } \\
\text { between Periods }\end{array}$ & $\begin{array}{l}0.002^{\cdots} \\
(0.000)\end{array}$ & $\begin{array}{l}0.002^{\cdots} \\
(0.000)\end{array}$ & $\begin{array}{l}0.002^{\cdots} \\
(0.000)\end{array}$ \\
\hline $\begin{array}{l}\Delta \text { Industry Log } \\
\text { Mean Earnings } \\
\text { between Periods }\end{array}$ & $\begin{array}{l}-0.003 \\
(0.011)\end{array}$ & $\begin{array}{l}-0.035^{\cdots} \\
(0.011)\end{array}$ & $\begin{array}{l}-0.026^{*} \\
(0.011)\end{array}$ \\
\hline $\begin{array}{l}\text { Index for Start of } \\
\text { First Period }\end{array}$ & $\begin{array}{l}0.040^{\cdots} \\
(0.001)\end{array}$ & $\begin{array}{l}0.029^{\cdots} \\
(0.001)\end{array}$ & $\begin{array}{l}0.024^{\cdots} \\
(0.001)\end{array}$ \\
\hline $\begin{array}{l}\text { Job Tenure at } \\
\text { Start of First } \\
\text { Period }\end{array}$ & $\begin{array}{l}0.017^{\cdots} \\
(0.001)\end{array}$ & $\begin{array}{l}0.019^{\cdots} \\
(0.001)\end{array}$ & $\begin{array}{l}0.014^{\cdots} \\
(0.001)\end{array}$ \\
\hline $\begin{array}{l}\text { Individual Log } \\
\text { Mean Earnings in } \\
\text { First Period }\end{array}$ & $\cdots$ & $\begin{array}{l}-0.153^{\cdots} \\
(0.002)\end{array}$ & $\begin{array}{c}-0.155^{\cdots} \\
(0.002)\end{array}$ \\
\hline $\begin{array}{l}\text { Time Interval } \\
\text { between Jobs }\end{array}$ & $\cdots$ & $\cdots$ & $\begin{array}{l}-0.009^{\cdots} \\
(0.000)\end{array}$ \\
\hline $\begin{array}{l}\text { Adjusted } \mathrm{R}^{2} \\
\text { Statistic } \\
\text { Number of } \\
\text { Observations }\end{array}$ & 0.182 & 104,327 & 0.226 \\
\hline
\end{tabular}

Significantly different from zero at $10^{\circ}{ }_{n}$ level using a two-tailed test Significantly different from zero at $5^{\circ}$ " level, using a two-tailed test. Signilicantly different from zero at $l^{\circ}$ " level using a two-tailed test. Notes: Data provided by Statistics New Zealand from the Linked Employer-Employee Database (LEED). The Mean Firm Employees" are measured in thousands for this regression. The variable Index for Start of the First Period measures in years when the lirst period started (April 1999 is sel eyual to 2 ero). The variable Job Tenure at Start of First Period measures in years the consecutive months in the job held in the first period sine the start of our sample period in April 1999. The Interval Between Jobs" is also measured in years.

Finally, we find evidence of a strong regression toward the mean among job changers. The estimated coefficient on this variable is negative and significant at better than a one pereent level. These results suggest that a 10 pereent increase in real monthly earnings in the first period is associated with an average decrease in the growth in earnings between periods of more than 1.5 percent. Higher initial earnings generally lead to smaller subsequent increases in individual earnings.

\section{Conclusions}

This study has provided some preliminary empirical results on the extent and nature of job mobility in New Zealand, and its possible effects on individual earnings. This analysis required data on individual employment and earnings histories, which was provided by Statistics New Zealand from the Linked Employer-Employee Data (LEED). Administrative data taken from monthly, employer PAYE reports to the Inland Revenue Department allow us to follow individuals through job transitions and their associated effects on the earnings. The LEED also makes it possible to examine the role of some individual, firm and industry characteristics on these outcomes

Consistent with overseas studies, there is evidence of both a great deal of job churning and job stability in New Zealand. More than four-fifths of employees work for a single employer in any year. Once in a job for more than two years, the probabilities of leaving that job decline substantially. Yet, at any point in time nearly one-third of workers have been in their jobs for less than one year, and almost one-half of workers have been in their jobs for less than two years. A great deal of job churning occurs over the first few years in a job. For example, estimated monthly hazard rates for teenagers and young adults (the probability of terminating a job in any given month) can be as high as 10 percent. This job churning dissipates over time. Hazard rates can fall below 2 percent after three or more years of job tenure. These observations are consistent with theories of job matching behaviour. Poor matches between firms and workers dissolve early in the relationship, while good matches endure for much longer periods of time.

Differences in hazard and survival rates were estimated by age and gender. Job mobility was found to be negatively related to age. Among teenagers and young adults, only about one job in twenty lasts for 52 or more weeks. Yet, among older adults, more than one job in six will last for at least that same period. Somewhat surprisingly, overall job mobility was found to be largely unrelated to gender. For younger and middle-aged workers, job mobility was relatively higher for males over the first two years in a job, but relatively higher for females after two years on job tenure. Differences between males and females in the probability of staying in a job for 52 weeks or more were negligible. In fact, among individuals aged between 45 and 64 , survival rates were found to be consistently higher for women.

To gauge the impact of job mobility on earnings, we compared two samples constructed from the LEED data. Our 'job stayers' were individuals who remained with the same employer for at least two years, while job changers' were individuals who switched employers, but remained with an employer for at least one year both before and after this job transition. In this way, we could 
compare the earnings trajectories of job changers before and after this transition and relative to the experiences of this 'counterfactual' group.

Overall, individuals changing jobs received lower earnings than those remain with their employers. Average growth rate in earnings between periods were found to be higher for job changers. Mean real monthly earnings increased between periods by 4.8 percent for job stayers and 5.9 percent for job changers. The implication is that job mobility may provide mechanism for individuals to raise their earnings.

The relationship between job mobility and earnings is found to be complex. Earnings profiles show that the narrowing of the earnings gap between job stayers and job changers is the result of both an increase in the 'starting salary' in the new job (equivalent to an intercept change in the earnings profile) and a slightly faster growth in monthly earnings over both periods (equivalent to an increase in the slope of the earnings profile). But this positive intercept change is relegated to those with initially low earnings. For job changers with initially high earnings who spend more than one month between jobs, the intercept change is negative.

Because of the large number of factors that could influence individual earnings in addition to a job change, some simple regression models were estimated. In the first set of regressions, the difference between the natural logarithms in real mean monthly earnings between the two periods (i.e., a proxy for the growth rate in earnings) was regressed against several groups of covariates. The estimated effect of a job change on the growth in earnings was highly dependent on the inclusion of other variables in the regression. When a dummy variable for a job change was included as the sole explanatory variable, a small but positive and statistically significant effect on earnings growth was found. When controls for age and firm characteristics were added, this estimated effect of a job change became negative and significant. This basic result continued to hold as other covariates were added to the regression model.

One thing that does come through in these regressions is the importance of firm characteristics for earnings growth. This result holds for both job stayers and job changers. Although job transitions in general may have little impact on the growth in earnings, moving to an employer that generally pays higher average monthly earnings tends to a growth tends to substantially increase individual earnings. Similarly, moving to a larger firm (i.e., one with more employees) is also associated with a higher growth in individual earnings. Job changes themselves generally lead to a slight decrease in earnings growth, and this negative effect becomes larger as the time interval between jobs increases. Only a job change that results in a move to a larger, higher-paying firm can be expected to lead to a faster growth in individual earnings.

\section{Future Research}

There is much more work to be done in this area before we can get a definitive picture of the relationship between job mobility and individual earnings. At this point, it would be difficult to say how important job mobility is to the average level of earnings or the overall dispersion of earnings in the labour market. One important element in any future analysis on this topic will be to obtain some direct or indirect information on the hours worked by these individuals each month, so that we could move from monthly earnings to something closer to hourly earnings. This issue, and a number of other concerns raised in this current report, should be addressed in future research in this area. In addition, information on the reason for a job separation may add substantially to our understanding of the relationship between job mobility and earnings. At this point, no information exists in the LEED that would distinguish between a job quit and job dismissal or redundancy. Some of what we are currently finding in this study on the various measurable determinants of earnings changes may be related to this missing variable.

\section{Notes}

I This research report was commissioned by Statistics New Zealand as part of its Official Statistics Research programme. Research funded through this programme is intended to strengthen the Official Statistics System by improving statistics and increasing the understanding of those statistics. Special thanks go to Wesley Thompson of Statistics New Zealand who was responsible for producing the raw data, descriptive statistics and regression results reported in this paper. The final version of this paper benefited from the comments of Dave Maré, Sylvia Dixon and other anonymous referees. Any remaining errors are my own.

2 Both studies currently have around one thousand or fewer respondents. Interviews have been conducted at approximately five-year intervals after these respondents reached adulthood. Both small sample size and infrequent interviews would be problematic for any analysis of job mobility.

3 Two drawbacks of these data are that these employment histories exclude any selfemployment and employment that results in earnings not reported to IRD (i.e., earnings generated from the underground or cash economy). The former is likely to be added to this database in the future.

4 The LEED could be considered a census rather than a survey, since these administrative data capture all reported employment relationships that involve income taxes withheld from employee pay and remitted to Inland Revenue. Yet, it is referred to as a 'sample' because it does not include the self-employed and employment relationships where income taxes are not withheld (i.e., those 
associated with the underground or cash economy).

In situations where the individual has earnings from multiple employers over the sample period, relevant information will be taken from the dominant employer (the one with whom the individual receives the highest earnings). See Holzer et al (2004) for a similar definition of the 'primary job'.

Given the restrictions of our sample period, a maximum of 24 months of tenure in a job was considered sufficient to provide some information about the extent of churning in the labour market. These observation periods can be increased in the future as more months are added to the LEED.

Again, we have no direct information in the LEED data on which of the two parties might have initiated the job separation. We cannot distinguish between 'job quits' and either 'dismissals' or 'redundancies' in this data set.

It would be a useful extension of this research to consider the earnings patterns of workers who change jobs with less stable employment histories on either side of this event, or with multiple job changes within a short time interval.

A number of key decisions had to be made in selecting observations on job changing and job staying behaviour. Firstly, the history of a single individual could contribute more than a single observation to our samples. For example, someone could have a long period of stable employment, followed by a job transition to another firm. We decided at the outset that any individual could contribute at most one observation to either the job changing or job staying samples. Secondly, we searched for these observations of these employment histories in a particular sequence. Examples of job changing behaviour were selected first. Examples of job staying behaviour were then taken from the remaining individuals. Finally, this search was conducted in reverse chronological order. We started with the last month in our dataset (April 2004 ) and worked backward in time. This was done to provide some variation in the observed tenure of individuals in their jobs in the first period back to the first month in our sample period (April 1999). In the end, job tenure in our sample is censored and can not exceed much more than three years in length.

10 Numbers of employees in firms were surprisingly high. This is due largely to the way in which the employer is defined in LEED. Firm employment is aggregated across multiple geographic locations. Someone working in a retail outlet, for example, is assigned the aggregate employment of that firm in all similar outlets throughout New Zealand and not the number of workers in that particular location.
One concrete example involves school teachers. The number of employees in this case is not the number of teachers in a particular school, but the number of school teachers in the country. Any future analysis of the importance of firm size for individual earnings should distinguish between the overall number of employees for an employer, and the number of employees in a particular geographic location.

11 All dollar figures reported here are inflated to January 2005 dollars using the Consumer Price Index.

12 It should be noted that these 12-month periods for the two groups may not correspond to comparable calendar periods. Although earnings information is taken from 24 consecutive months for job stayers, the two 12-month periods for job changers may be separated by a number of months or even years. During a period of steady growth in real earnings this would tend to increase the relative growth in earnings of job changers between periods. We address this issue in subsequent sections of this report by separately controlling for the length of the time interval between jobs for this job-changing sample.

13 Note that the dollar units of the vertical axes are different between Figures 7 and 8.

14 As before, the sample is restricted to individuals who had at least 24 months in the same job (job stayers) or two 12-month periods in different jobs on either side of a job transition (job changers).

15 Age is divided by 10 before inclusion in this regression. This was done to make the coefficient estimates meaningful within the first few places to the right of the decimal point.

I6 The variable is set equal to zero for individuals who don't experience a job change. The number of months in transition is equal one if an individual took one month or more to find a new job, two if they took between two months or more, etc.

\section{References}

Abowd, J. and Kramarz, F. (1999). The analysis of labor markets using matched employer-employec data. In Ashenfelter, O. and Card, D. (eds.) Handhook of Labor Economics, Vol. 3B. Amsterdam: North-Holland.

Black, D. and Loewenstein, M. (1991). Self-enforcing labor contracts with costly mobility. Research in Labor Economics, 12, 63-68.

Borjas, G. (1981). Job mobility and earnings over the life cycle. Industrial and Labor Relations Review, 34(3), 365-377. 
Burgess, S., Knetter, M. and Michelacci, F. (2000). Employment and output adjustment in the OECD: A disaggregate analysis of the role of job security provisions. Economica, 67, 419-435.

Burgess, S., Lane, J. and Stevens, D. (2000). Job flows, worker flows and churning. Journal of Labor Economics, 18(3), 473-501.

Crichton, S., Stillman, S. and Hyslop, D. (2004). Returning to Work from Injury: Longitudinal Evidence on Employment and Earnings. Unpublished Working Paper. Wellington: Statistics New Zealand.

Diebold, F., Neumark, D. and Polsky, D. (1996). Comment on Kenneth A. Swinnerton and Howard Wial, Is job mobility declining in the U.S. economy? Industrial and Labor Relations Review, 49, 348-352.

Farber, H. (1999). Mobility and stability: The dynamics of job change in labor markets. In Ashenfelter, O. and Card, D., (eds). Handbook of Labor Economics, Vol. 3B, Amsterdam: North-Holland.

Gladden, T. and Taber, C. (2000). Wage progression among less-skilled workers. In Card, D. and Blank, R., (eds.), Finding Jobs. New York: Russell Sage Foundation.

Gottschalk, P. and Maloney, T. (1985). Involuntary terminations, unemployment and job matching: A test of job search theory. Journal of Labor Economics, 3(2), 109-123.
Hammida, M. (2004). Job mobility and hourly wages: Is there a relationship? Monthly Labor Review, 127, 23-30.

Holzer, H., Lane, J. and Vilhuber, L. (2004). Escaping low earnings: The role of employer characteristics and changes. Industrial and Labor Relations Review, 57(4), 560-578.

Hyslop, D., Stillman, S. and Crichton, S. (2004). The Impact of Employment Experiences on Benefitto-Work Transitions. Unpublished Working Paper, Wellington: Statistics New Zealand.

Munasinghe, L. and Sigman, K. (2003). A hobo syndrome? Mobility, wages and job turnover. Labour Economics, 11, 191-218.

Royalty, A. (1998). Job-to-job and job-tononemployment turnover by gender and education level. Journal of Labor Economics, 16(2), 392-443.

Swinnerton, K. and Wial, H. (1995). Is job mobility declining in the U.S. economy? Industrial and Labor Relations Review, 48, 293-304.
Author
Tim Maloney
Associate Professor
Economics Department
The University of Auckland
Private Bag 92019
Auckland Mail Centre
Auckland
T.Maloney@auckland.ac.nz 